\title{
Examining Temporality and Difference: an Intensive Approach to Understanding Medieval Rural Settlement
}

\author{
Ben Jervis $^{1}$ (D) \\ Accepted: 24 February 2022 / Published online: 7 March 2022 \\ (c) The Author(s) 2022
}

\begin{abstract}
A new theoretical approach to medieval rural settlement, built on the concept of intensity, is proposed. It is argued that analysing settlements as intensive spaces creates new opportunities to explore the emergence of difference in medieval lived experience. The approach is intended to overcome the challenges posed by approaches to medieval architecture framed by binary divisions (e.g. inside/outside). Drawing on posthuman thought, it is argued that such divisions constrain the understanding of how and why difference emerged in the past. The paper advances this approach through its application to the study of house construction and domestic economy in the medieval village of Hangleton, England. It is proposed that difference emerges as everyday practices are performed in constantly changing material environments, generating situationally grounded but varied experiences of rurality. Rather than being subject to macro-scale economic processes, this approach allows us to understand historical change as a patchwork of localised interactions which overflowed the bounds of communities or regions.
\end{abstract}

Keywords Rural life $\cdot$ Medieval $\cdot$ Architecture $\cdot$ Household $\cdot$ Intensity $\cdot$ Posthuman

\section{Introduction}

Intensity is probably the last word that comes to mind when thinking about the medieval countryside. It is a concept which creates possibilities to think about rural communities as dynamic and differentiated (Heley \& Jones, 2012) and to explore how temporality, materiality and agency are intertwined in the production of difference (Hamilakis, 2017, 173-5). The medieval peasantry is often homogenised as a subaltern group, a perception shaped both by a nineteenth century Romantic ideal and ethnographic studies (e.g. Schofield, 2003, 2-3; Quirós-Castillo \& Tejerizo García, 2020). For Duby, the peasant voice was muffled or obscured by the ruling

Ben Jervis

jervisb@cardiff.ac.uk

1 School of History, Archaeology and Religion, Cardiff University, Cardiff CF10 3EU, UK 
classes of medieval society (Lardreau \& Duby, 1987, 70; discussed by Freedman, 2001, 269). Examinations of class struggle have emphasised community identity, held up in opposition to external power, a view which analyses of conflict and difference within medieval villages call into question (Schofield, 2003, 5; Müller, 2007, 185). As Dyer (1994, 418) states 'every village, almost without exception, had a heterogeneous population'. This heterogeneity surfaced in terms of wealth, political authority and economic specialisation, as well as in relation to the lifecourse (see Gilchrist, 2012). Peasant communities were formed of multiple and overlapping sets of relations (Müller, 2007, 117). This variability is visible archaeologically in the diverse range of built forms that peasant houses, settlements and landscapes take (Mileson, 2015; Smith, 2010).

A major theme in the study of peasant experience, particularly apparent in analyses of domestic space, has been binary formations. It is now established that the mapping of gendered distinctions on to concepts of inside/outside or domestic/economic within an explicitly patriarchal regime of power is limiting (see Smith, 2007; Olson, 2016 for critique), yet these approaches persist because they do relate to a certain degree to medieval perceptions of gender which can be clearly observed in contexts such as the church and elite buildings. Binary thinking is an effect of the homogenisation of class difference framed by a pre-occupation with 'feudal' relations (which were actually extremely diverse; Wickham, 2021, 11) and an approach to medieval villages predicated on a notion of scale, which creates a view of society as nested scales of organisation (e.g. household, village, manor) on to which binary distinctions can be imposed (see Jones et al., 2007, 267). In critiquing these approaches, historians and archaeologists have attempted, with some success, to pick apart dynamics of power, for example, through assessing the role of rural communities in shaping settlement landscapes, including through the emergent land market (e.g. Rippon, 2008; Jones and Page, 2006; Jones, 2010; Platt, 2016; Rippon $\&$ Morton, 2020) and the complex breakdown of serfdom (Bailey, 2014). The introduction of analyses of gender to the study of rural communities has created opportunities to grapple with the medieval 'matrix of oppression' in which experience can be understood intersectionally (e.g. Bennett, 1997; Müller, 2013; Olson, 2016). As Beatriz Marín-Aguilera (2021) has recently argued, such approaches are essential to understanding the heterogeneity of subaltern groups and how agency was distributed unevenly across communities by dissolving dichotomous thinking (see also Voss, 2008). It is, therefore, well established that the peasant experience in medieval England was neither uniform nor stable. The aim of this contribution is to examine how the study of material remains can transfer focus from the representation of difference to its constitution, through the employment of a concept of intensity and an understanding of temporality which implicate the non-human in rural sociality.

Intensity is a concept drawn from the writing of Deleuze and Guattari (1987, 165). Although ostensibly offering a critique of the nineteenth and twentieth century philosophical canon, Deleuze and Guattari's writing is valuable for medieval scholarship for several reasons. Firstly, although built on some problematic assumptions about the nature of feudalism, they offer an approach to economic and social becoming which is non-linear (Deleuze \& Guattari, 1983, 276-301). As such, it provides a means to understand experiences as contextually contingent and diverse, offering 
a valuable means to critique generalising models of economic and social development (e.g. Jervis, 2018, 2022). Secondly, by de-centring human agency in historical processes, they create a space in which the role of objects, materials and other non-human elements become implicated in change. This has resonance for the study of a period in which materials were potent participants in religious practice (e.g. Walker Bynum, 2015) and the performance of personhood (Cohen, 2005). Finally, and of the most relevance here, they provide an ontological toolkit for understanding dynamics of persistence and change, in which it is repetition, rather than change which requires explanation once we accept that we inhabit a world of fluid and generative relations.

To attend to space as intensive, rather than extensive, is a challenge to established archaeological methods. Archaeologists typically think of space as extensive, as demonstrated by representations of buildings in plan for example. Intensities are closer to an ever-changing weather map depicting fluid and unfolding relations (DeLanda, 2005, 2016, 76). To attend to rural communities as intensities is therefore to attend to practice, to lived experience and to the specific unfolding contexts of rurality. Intensities, then, are coming-together, generative happenings or assemblages (Braidotti, 1994, 56; DeLanda, 2016, 76). Assemblages are fluid configurations of relations, momentary 'territorialisations' or gatherings of diverse elements which are simultaneously emergent and generative (Deleuze and Guattari, 1987, 102-3; Bennett, 2010, 23-4; DeLanda, 2016, 12-13; see Jervis, 2019). This approach has distinct advantages; it removes the need to map stratified scales onto extensive space and decouples scale from the binary endpoints of neighbourhood (micro) and global (macro), allowing local practices to be productive of difference rather than articulations of global processes (Jones et al., 2007, 265). An extensive understanding of peasant communities might focus on how village layouts, fields or houses are meaningful materialisations of peasant society (e.g. Smith, 2010; Mileson, 2015). A focus on intensities challenges the simplistic mapping of gender and other social dynamics on to extensive space, linking spatial formations to temporal processes (e.g. Olson, 2016; Catlin, 2016; Beck, 2017). In short, an intensive perspective allows us to understand how worlds emerge through living with the material, rather than being encapsulated in material form (Cohen, 2005, 5). This approach establishes a creative tension between an ontological commitment to an unfolding and unpredictable world of relations and certain binaries of gender and power which were recognised in the Middle Ages, as can be seen clearly, for example, in gendered distinctions imposed on religious experiences in both parish churches and religious houses (e.g. Gilchrist, 1994; French, 2005). A key concern of contemporary post-human feminist scholarship is to understand how and why these binaries emerge, are maintained and intersect with lived experience (Stark, 2017, 33). An intensive approach therefore provides an opportunity to examine this tension to dissolve binaries as an a priori analytical construct but also to understand how they were a determinant in the emergence of multiple modes of rural becoming (Braidotti, 1994, 94-9; 2013, 96-9; Jones et al., 2007, 272). The potential of this approach for revealing difference in medieval communities will be explored through an analysis of a particular medieval settlement, Hangleton, England. 


\section{Temporality, Difference and Space}

An illusion of stasis constrains the understanding of difference (Bennett, 2010, 33-4; Braidotti, 1994, 50; 2013, 188-9; Cohen, 2015, 125; Irigaray \& Marder, $2016,47)$. The medieval house seems to be a stable structure, from which we can extract meaning. But what meaning are we seeking, and what is the ontological position of the 'types' of spatial organisation that we identify (Beck, 2017, 2018; Johnson, 2013)? Emerging from a conscious desire to theorise medieval buildings, approaches which seek a shared architectural 'grammar', a materialisation of habitus (a shared unconscious material and social knowledge; after Bourdieu, 1977), have dominated their study (e.g. Austin \& Thomas, 1990; Johnson, 1993; Grenville, 2008; Suggett, 2013). This work suggests a shared understanding of space across medieval society, with the concept of a 'high' and 'low' end, most visibly present in the layout of the church, being seen in domestic, religious and civic buildings (e.g. Gilchrist, 1994; Giles, 2000; Gardiner, 2008).

There is a strong awareness that approaches which map dichotomies (inside/ outside, male/female, public/private) on to this grammar conceal differences in domestic organisation (see also Smith, 2010, 82-3; Rees Jones, 2013, 248; Olson, 2016). Whilst such approaches provide a useful tool for thinking through space, the advent of more nuanced and contextualised approaches to gender has highlighted the need to develop alternatives. As Flather (2013) argues in relation to early modern houses, the fluidity of gender roles, identities and agency means that any mapping of space and gender as a stable system of meaning erases diversity in both identities and the use of space. A similar conclusion was reached by Goldberg (2011) who argued that within medieval peasant houses at least, any sense of gendered spheres is not supported either by the evidence for the range of activities in which men and women were engaged, or for the spaces they inhabited. Rather, as Olson $(2016,225)$ argues, multiple spaces were created through diverse experiences, as has been demonstrated through nuanced analyses of spatial organisation, gender and movement in higher status buildings (e.g. Gilchrist, 1999; Richardson, 2003). We can perceive of houses as 'sites' not in the sense of being spatially defined locales for action, but as elements of 'dynamically composed aggregate(s) whose 'map' is drawn according to [their] own internal 'logics' rather than as generalising laws' (Woodward et al., 2010, 273).

Excavations at Hangleton, a medieval village on the outskirts of the modern city of Brighton and Hove in south-east England, which shrunk and was eventually deserted in the period after the Black Death, revealed multiple buildings, most of which are likely to be houses (Holden, 1963; Hurst \& Hurst, 1964; Fig. 1). Excavation shows the village to have a linear form, aligned along a road with the church at the western end and the manor house beyond. The site is situated on the downslope of the chalk downland (Fig. 2), overlooking the narrow coastal plain and the sea beyond. Table 1 demonstrates these structures to be highly variable in their size and form. Several houses have evidence of an earlier timber phase, being rebuilt in locally sourced flint in the thirteenth century. By the fifteenth century, they were largely abandoned, with there being strong evidence for the merging of plots and the 


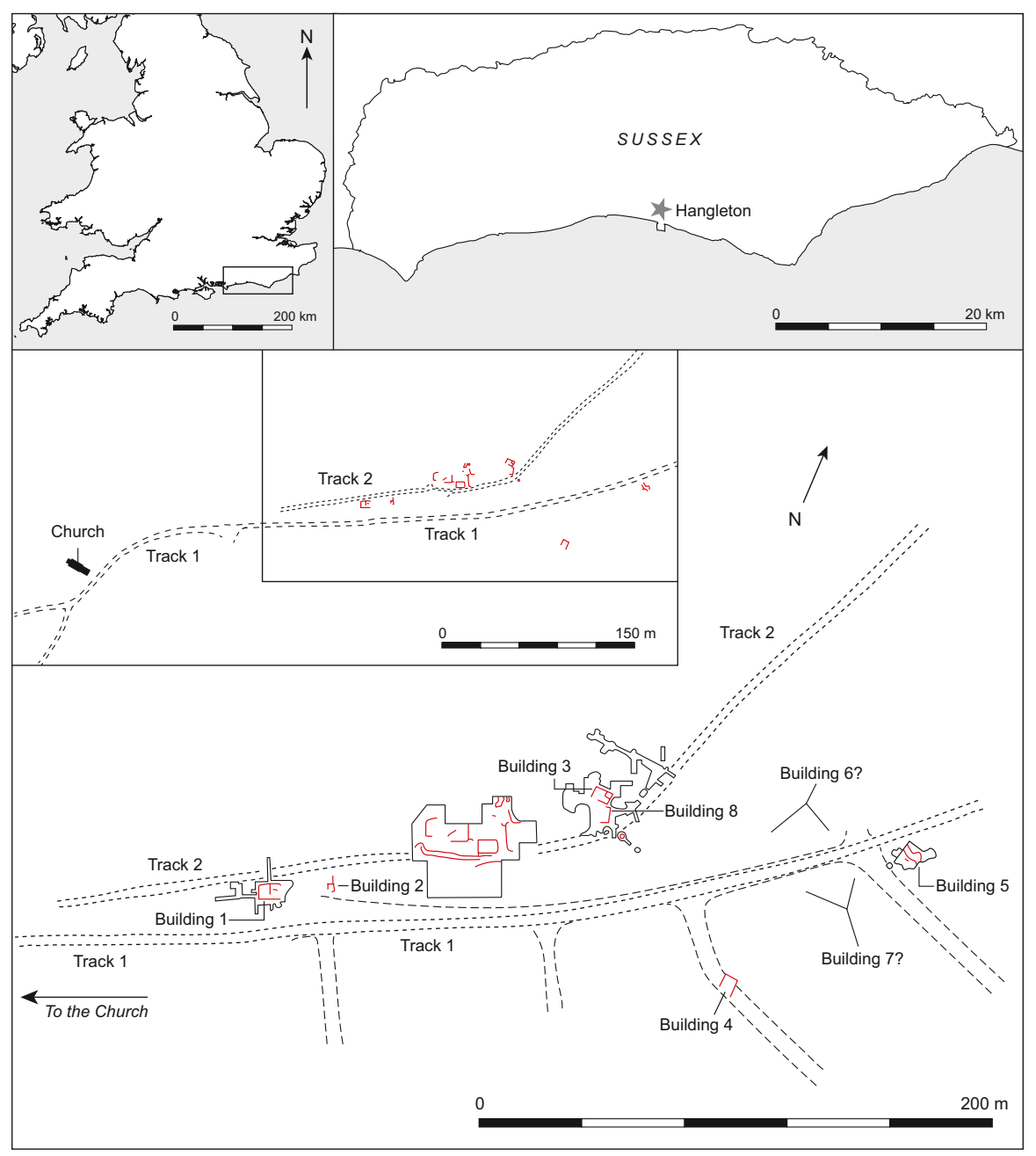

Fig. 1 The location of Hangleton in south-east England, plan showing the relationship between excavated buildings and the church of St Helen and plan of excavated and earthwork features at Hangleton (redrawn by Gethyn Long and Kirsty Harding after Holden, 1963)

erection of new houses and ancillary buildings. The artefacts from the site paint a picture of a community engaged in agrarian husbandry (e.g. plough fittings, sickles), small scale crafts (e.g. spindle whorls) with access to coastal resources (e.g. beach pebbles refashioned as whetstones and oysters) and markets (e.g. imported stone objects and non-local pottery). Situated on chalk downland, the village had a mixed agrarian economy, with sheep pasture on the chalk upland and arable cultivation in the fertile scarps which run to the south. Nucleated settlements of similar form are common along the coastal plain, giving way to more isolated farmsteads deeper into the chalklands and the clay Weald beyond (Wrathmell \& Roberts, 2003). 


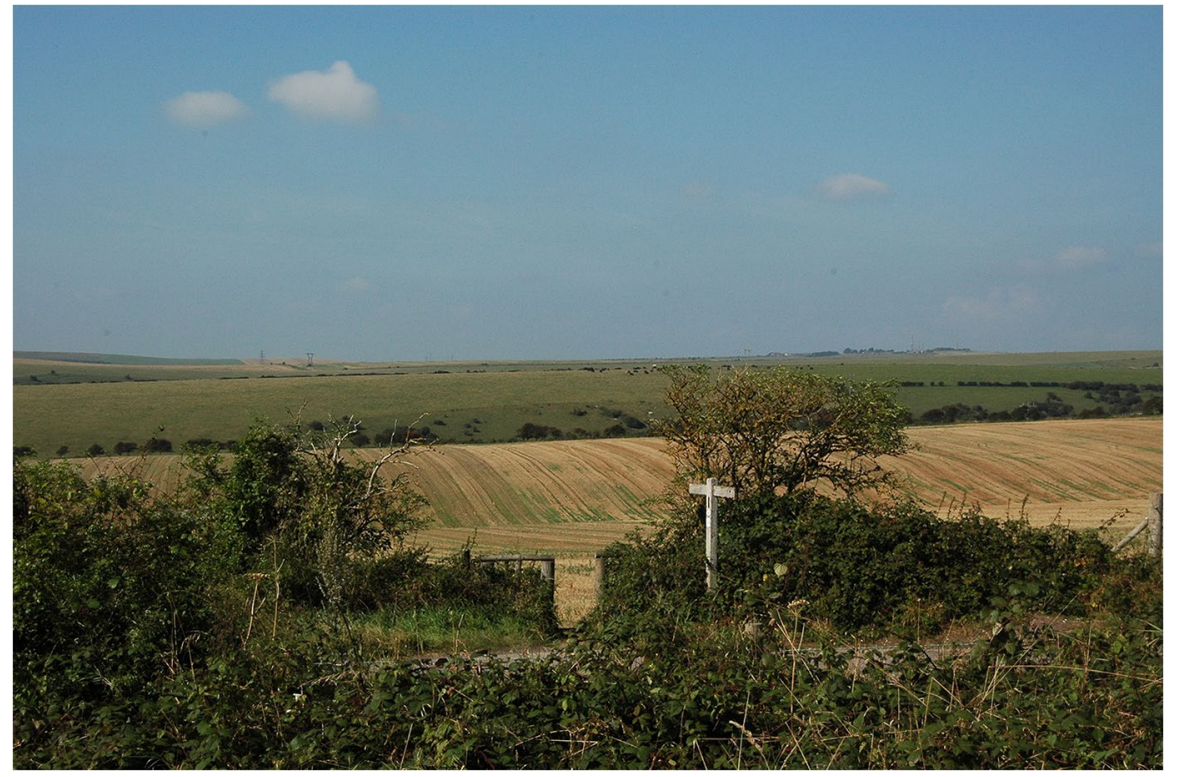

Fig. 2 The landscape around Hangleton looking north over the rolling chalk downland above the village (photograph: Ben Jervis)

Building 1 at Hangleton (Fig. 3) vividly demonstrates Johnson's (2013) point about the ontological status of archaeological 'types'. Following excavation, the plan was drawn into comparison with other medieval houses and identified as an example of a 'longhouse' (Holden, 1963, 78). These houses, with byres for animals at one end and living space at the other, are common in upland areas of England, particularly the south-west (Alcock, 2015; Austin \& Thomas, 1990; Gardiner, 2014a, 2014b). This identification brings with it certain assumptions (see also Beck, 2018, 144). It implies small scale pastoralism, a close relationship between humans and animals which share a roof with the smells, noises and daily rhythms of feeding, pasturing and overnighting shaping household experience.

In an important paper, Gardiner (2000) demonstrated the ubiquity of the longhouse to have been erroneously claimed and proposed an alternative interpretation of Building 1. The lower room is too small to house animals and the building lacks other internal features associated with drainage. The house can be more comfortably understood as a three-cell dwelling. Gardiner postulates that 'byre' is in fact a chamber, with the central room containing a hearth and possible oven being a hall, with a service end (interpreted by the excavator as a later extension) beyond. Gardiner identifies similar spatial organisation in a number of other excavated twelfth-fourteenth century houses, arguing that they form a general medieval domestic plan which emerged as the result of experimentation by housebuilders and occupants. The diversity of earlier houses gradually coalesced around a more-orless standard form. This replaces one set of assumptions with another. The identification of Building 1 as a three-cell dwelling carries with it assumptions about the 


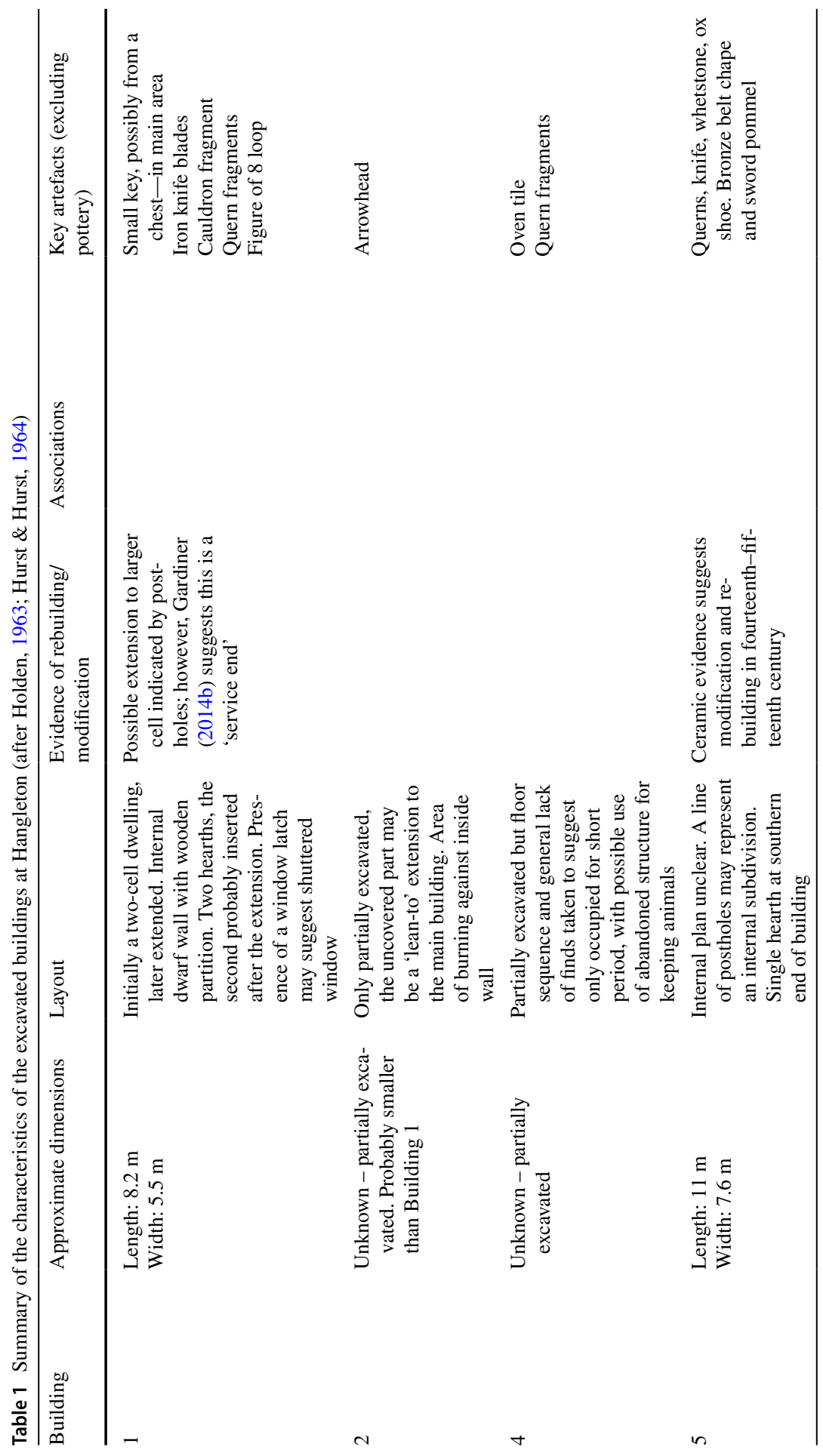




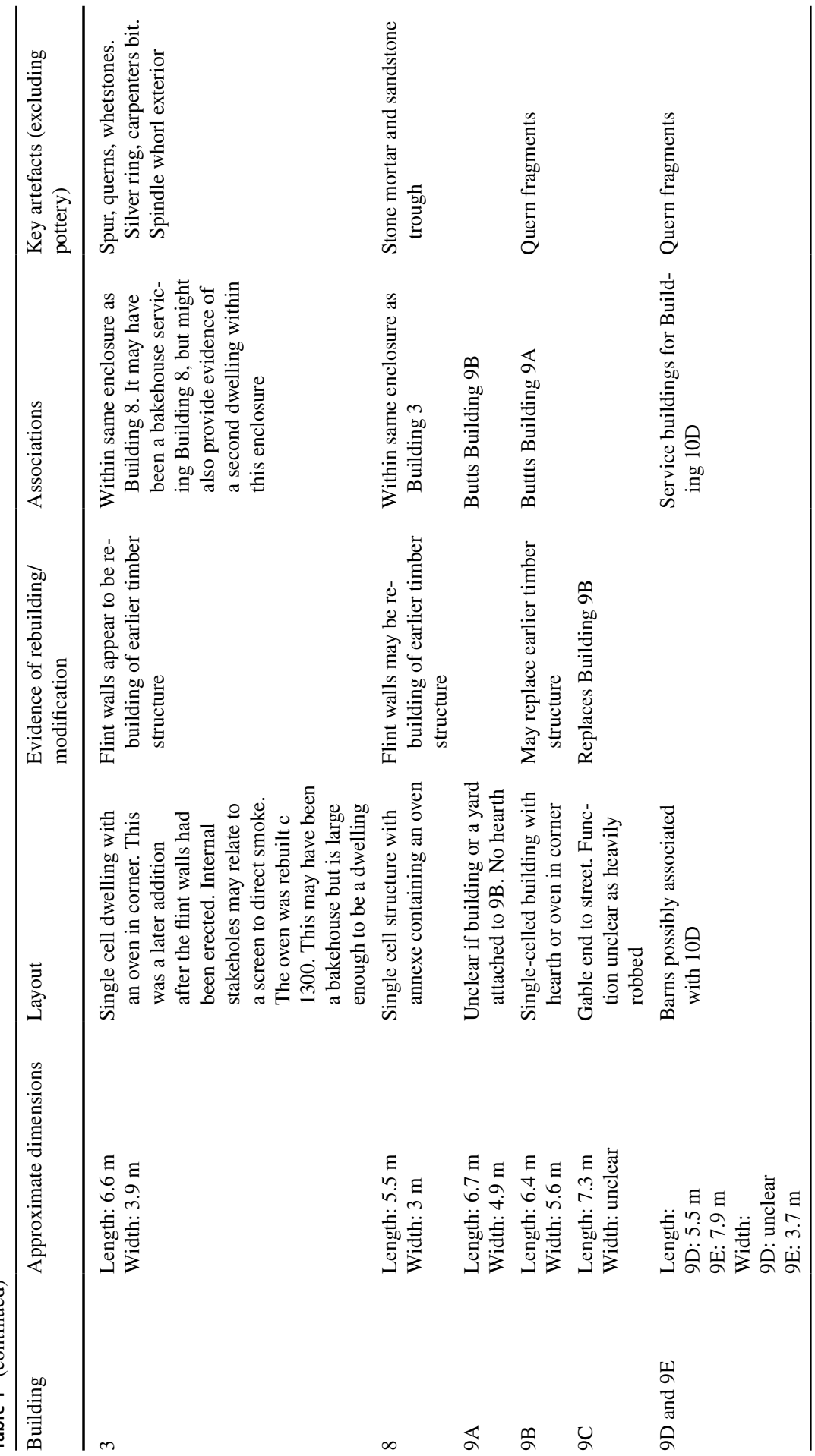




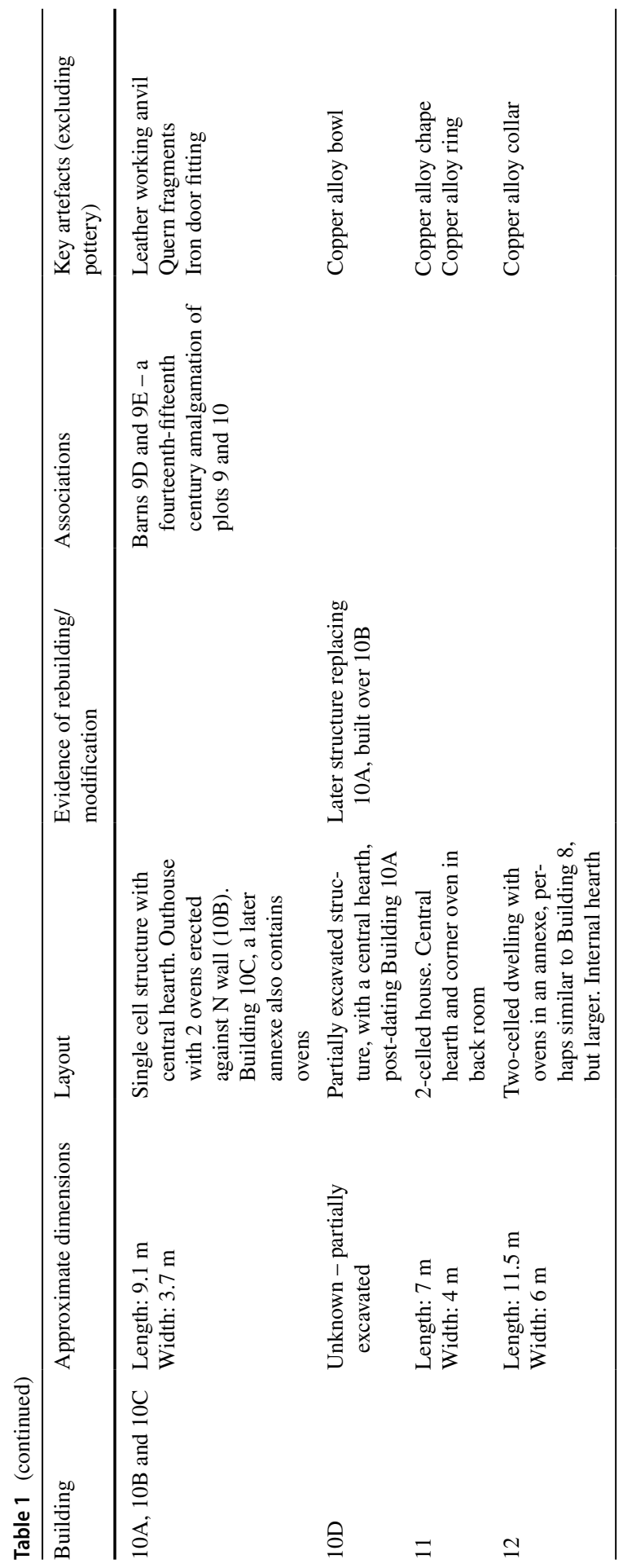




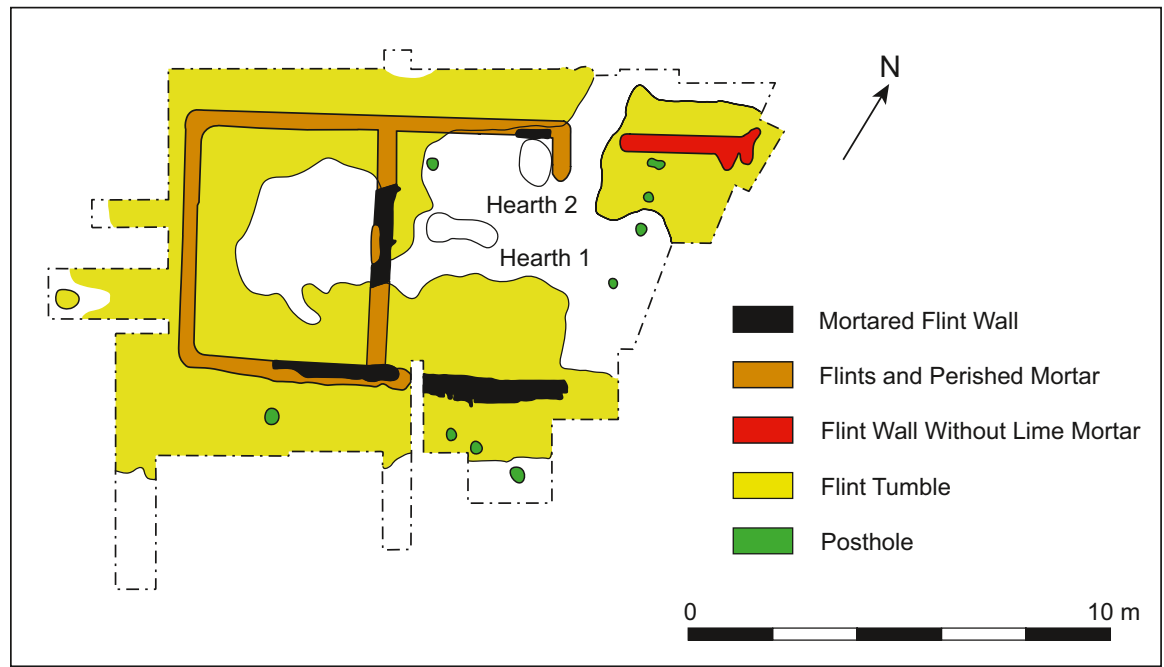

Fig. 3 Hangleton Building 1 (redrawn by Gethyn Long and Kirsty Harding after Holden, 1963)

use and organisation of these spaces and a sub-conscious awareness of spatial logic, specifically a distinction between public (the hall) and private (the chamber) space, mapped on to a hierarchical distinction of 'high' and 'low' ends. Whether identified as a longhouse or an example of a medieval plan, these characterisations of Building 1 are what Deleuze and Guattari $(1987,12)$ term a process of tracing, a repetition or replication. Tracing, as opposed to mapping, a cartographic and nomadic means of engaging with the world, supresses difference, repeating social structures rather than allowing alternative futures to emerge (Braidotti, 1994; Deleuze \& Guattari, 1987, 11-12; Cohen, 2005, 22 see also Jervis, 2019 89-90). For this reason, I develop an alternative approach, focussed on becoming, rather than meaning.

To achieve this, we can follow Johnson's (2013) call for a renewed focus on 'lived experience', an acknowledgement that buildings are used and experienced in a multitude of ways. Houses, like portable objects, have a 'biography', intertwined with those of their residents (Bütser, 2021; Weikert, 2015). An intensive approach demands that we shift our gaze from stable spatial formations to activities and processes, to understand the relations which comprise lived experiences of construction and dwelling (McFadyen, 2006; Bolender \& Johnson, 2016, 78). In turn, this requires holistic approaches to domestic life which integrate the study of buildings and objects (e.g. Briggs et al., 2019), and the negotiation of their multiple temporalities. Developing Austin and Thomas's (1990) analysis of the Dartmoor longhouse, Catlin (2016) has questioned the notion of a grammar relating to an illusory 'ideal' peasant house. She emphasises how houses change with the households who occupy them, suggesting that they may simultaneously be spaces for the assertion of patriarchal authority and female agency (see also Olson, 2016). Similarly, Smith (2010) emphasises diversity in lived experience of rural communities through examination of the heterogeneity of landscape and building organisation and Weikert (2018) explores the multiple intersections between space, power and gender. As Smith 
(2007, 316) argues, excavated houses lacking evidence for internal sub-divisions, such as buildings 3 and 8 at Hangleton, do not map onto a concept of a 'symbolically charged' domestic architecture, with lived experience leading to a range of spatial understandings.

Once we acknowledge that space changes with the unfolding of day-to-day life, it comes to be an active participant in lived experience, rather than a stage upon which life is performed. Houses are not intended to be static spaces but were constructed with a future in mind (McFadyen, 2007, 119). As the Deleuzian-inspired architect Eisenmann (1991) notes, form is changing at any given time; buildings are always 'becoming' (Williams, 2000; Bolender \& Johnson, 2016, 66; Beck, 2018, 155). Whilst features such as doors and walls are persistent features, they decay over time if not maintained. Whilst spaces persist in extensive form, as intensities they change as they are used and experienced differently through the day, as they fill with smoke, become warmer or colder, as furniture is re-arranged for eating or sleeping. They are more than solid spaces; they are fluid elements of an emergent sensory assemblage of medieval domesticity (see Hamilakis, 2017). Vivid examples are provided by references in inventories to trestles and mattresses rather than tables and bedsteads, suggesting a daily rhythm of spatial remodelling (Briggs et al., 2019; Dyer, 2013). This evidence finds a parallel in the long-running debates about the relationship between hall and chamber in medieval elite buildings. These buildings were clearly expressions of wealth and status, but might change function through altering its furnishings, fulfilling a different practical function, whilst maintaining its symbolic associations (Quinney, 1999). For the later medieval period, references to 'chambers' in wills, and indeed one medieval meaning of the term 'household', do not relate to extensive spaces, but rather to collections of material goods, suggesting space was defined less by its enclosure and more by the activities and relations constituted through it (Salter, 2006, 67; Rees Jones et al., 2007, 116-7; see also Briggs et al., 2019, 158). An intensive approach therefore accords with our understanding of how mediaeval space was perceived of and experienced, less a space with a fixed purpose and more a participant in fluid social processes. At Hangleton, the presence of an oven in the backroom of the two-celled Building 11 (Fig. 4), which might be interpreted as a chamber, points to the varied functions to which apparently 'private' spaces may be put. The oven would have provided welcome warmth if this area was used for sleeping as the spatial 'grammar' would suggest, but also drew this room into the domestic or economic activity of baking. Documentary references demonstrate that chambers could be used for the storage of crops (Claridge \& Langdon, 2011), the deeper space perhaps providing a sense of security or simply a means to ensure bulky goods did not disrupt daily activities.

Despite this fluidity, houses are durable. They persist through what I term their 'slow materiality'. As Woodward et al. $(2012,212)$ argue, matter is drawn into an 'impermanent consistency', in which things work together with or without the presence of a human subject. These materials are always changing but at a pace indiscernible to human perception. We may observe change at particular intensities, when a post finally gives way or a roof collapses, but these are culminations of ongoing transformations, not specific and isolated moments in time (see DeLanda, 2016, 76; Beck, 2017, 70; Crellin, 2020, 173-5). The house or village as a 'site' 


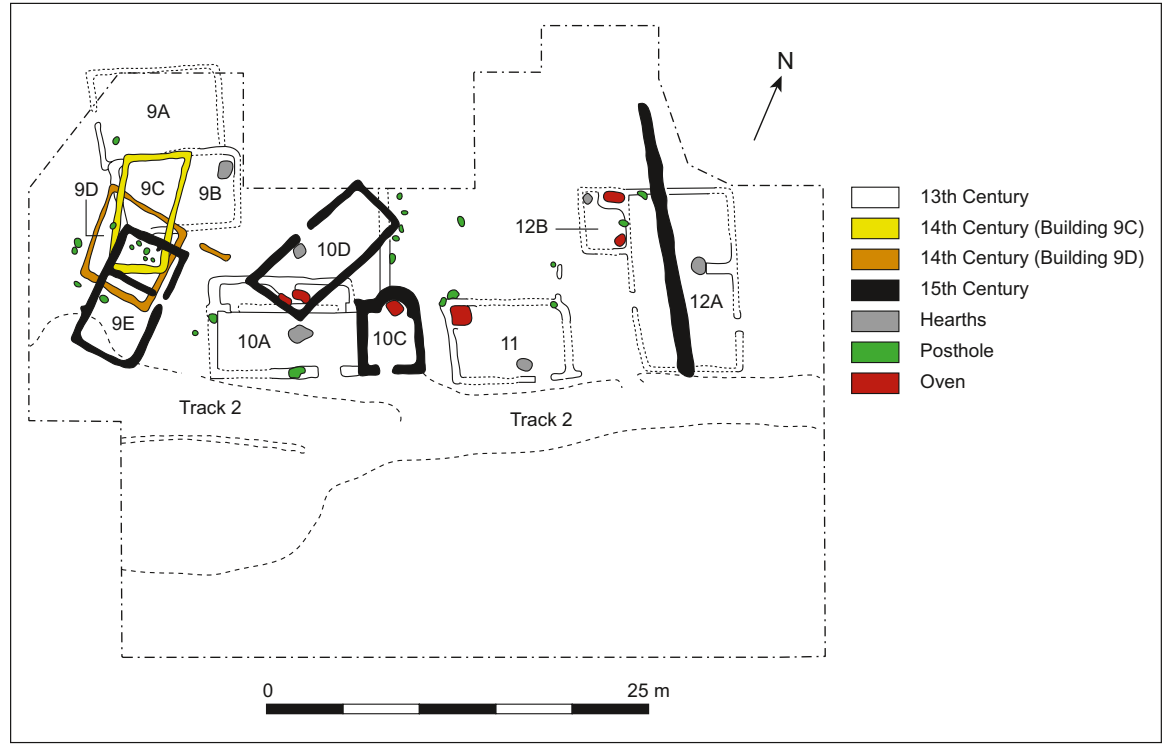

Fig. 4 Hangleton Buildings 9, 10 and 11 (redrawn by Gethyn Long and Kirsty Harding after Hurst \& Hurst, 1964)

is a 'dense event space' (Woodward et al., 2010, 278), an ongoing aggregation of labour in which human and non-human participants are implicated, in which the house demands what Cohen $(2015,59)$ terms 'sustained participation'. Ultimately, the question of spatial meaning can be understood as a concern with temporality, of materials, of domestic and community life, of custom and of the lifecycle (see Ingold, 1993) - they are event spaces of banal processes, 'unexceptional congealments of routine and repetitions' (Woodward et al., 2012, 210).

Van Oyen (2019) critiques the romantic 'timelessness' associated with rural societies, calling for examination of the open-endedness of rural life over emphasis of its cyclical nature (and the resultant sense of repetition; see also Bennett, 2010, 24; Woodward et al., 2012, 210). Furthermore, this timelessness might be equated to backwardness, dismissing the potential complexities of rural life. The concept of temporal syntheses developed by Deleuze (1968) in his thesis Difference and Repetition provides one set of tools for negotiating this challenge (see also Cohen, 2005, 11; Braidotti, 2013, 165). Deleuze argues that there are 3 temporalities, past, present and future, which exist simultaneously and within each other. The past is active within the present just as the present is always the futures past. The past is a process of repetition; we might think of the enacting of embodied skill or knowledge. The future is a process of differentiation; it is open-ended; we do not know what will emerge - it has potential. The present, then, is an intensity, a gathering of past things generative of different futures (Williams, 2019, 106; 116). This approach reveals temporality to be both non-linear, open-ended and therefore more than cyclical; whilst the agrarian calendar was an element of rural temporality, we should see this as an element of repetition with change, rather than providing a model of a stable 
and unchanging rural 'system'. This has been neatly visualised by Nail (2019), who draws on ideas of flow and fold to articulate the persistence of repetition and the emergence of difference (Fig. 5). A world of intensities is constantly in motion; it is an entangled flow of matter and ideas. These flows are undirected but are coded; they are historically contingent, shaped by the past as they form the present (see also DeLanda, 1997). In the present, these flows become folded, the fold acting as a filter; some flows loop back, performing repetition, others pass through, generating difference.

We can perceive of a house, settlement or landscape as a fold, its slow materiality being a filter for the entangled flows that emerge. This fold is more than material; it incorporates practice (such as rights of tenure), to knowledge and capability-ultimately, it constrains desire, the driving force of difference in Deleuze and Guattari's writing. A focus on the generative capacities of these spaces shifts our understanding from a perpetual loop of meaning to experiences of becoming, which are necessarily situated and heterogeneous. These processes are constrained by a politics of scale, of seigniorial and religious authority which shape built form and constrain action but retain the capacity to be generative of situated forms of power or difference (Woodward et al., 2012, 217). The emergent flows might be understood as threads; if we tug them hard enough, the fold loosens or comes undone. This tugging is a process of de-territorialisation, of pulling an assemblage beyond itself, of over-coding the flows, which may have the effect of liberating or constraining what might emerge, making a society which is more or less fluid, more or less rigidly differentiated (Deleuze \& Guattari, 1987, 557-60). It is these processes which we can explore through the excavated houses at Hangleton.

\section{Building Hangelton}

We can imagine the scene as, at the end of the thirteenth century, high on the chalk downland above Hangleton, the community worked the fields, encountering and collecting nodules of flint which both blunted their tools and could find use as a

Fig. 5 Representation of flow and fold (redrawn by Ben Jervis after Nail, 2019)

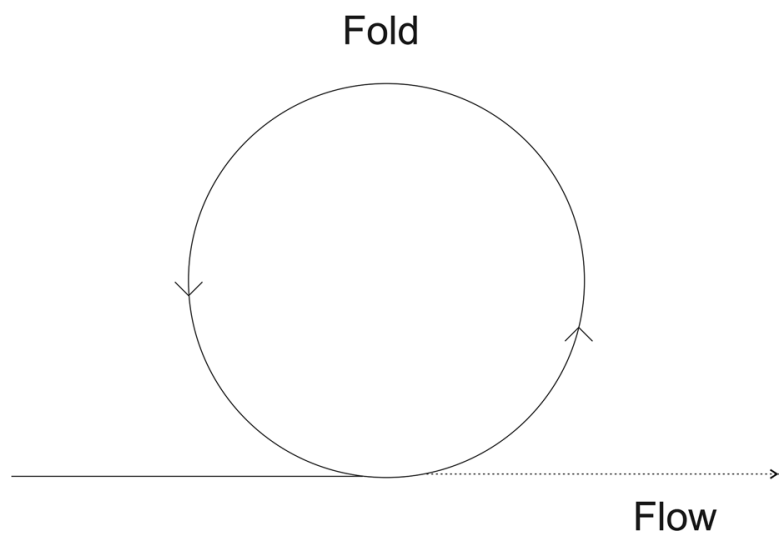


building material (Fig. 6). These encounters would have taken place in the context both of service to the manor and the working of land granted to the villagers. This scene can be framed as a simple manifestation of top-down coercive power, re-enforcing difference between lord and community. That peasants relied upon the manor for access to land certainly provided a strong coercive lever, but as uprisings in the fourteenth and fifteenth centuries show us, this could not be taken for granted (Mate, 1992). Lordship and community can be understood as institutions which 'shatter the linearity of time' (Braidotti, 2013, 74; see also Cohen, 2005, 11). They were performed in the present but rooted in the past. Power was not held by an individual but was dispersed across a relational web of legal practice, custom and obligation, landscapes, buildings, crops and livestock (see, for example, discussion of lordship by Dyer, 2007a and discussions of power by Braidotti, 2013, 93; Crellin, 2020, 126). Community cooperation and decision-making were critical to the management of resources in the medieval countryside (Hilton, 1973, 1990). The boundaries between communities could be fluid, with individuals a part of multiple groups (Müller, 2007). Just as manorial custom bound the community to place, so communal activities created fluid borders, interactions with the land and the material opening new spaces for co-operation and community becoming (Nail, 2019, 194-5). Both lordship and community were more-than-human in their composition, with materials providing an impetus and resource for community building (Harris, 2014, 91). The formal structures of lordship and village enfolded flows, perpetuating repetition. Where earlier timber structures could be identified at Hangleton, the rebuilding in stone closely follows their footprint. Rebuilding created a link to

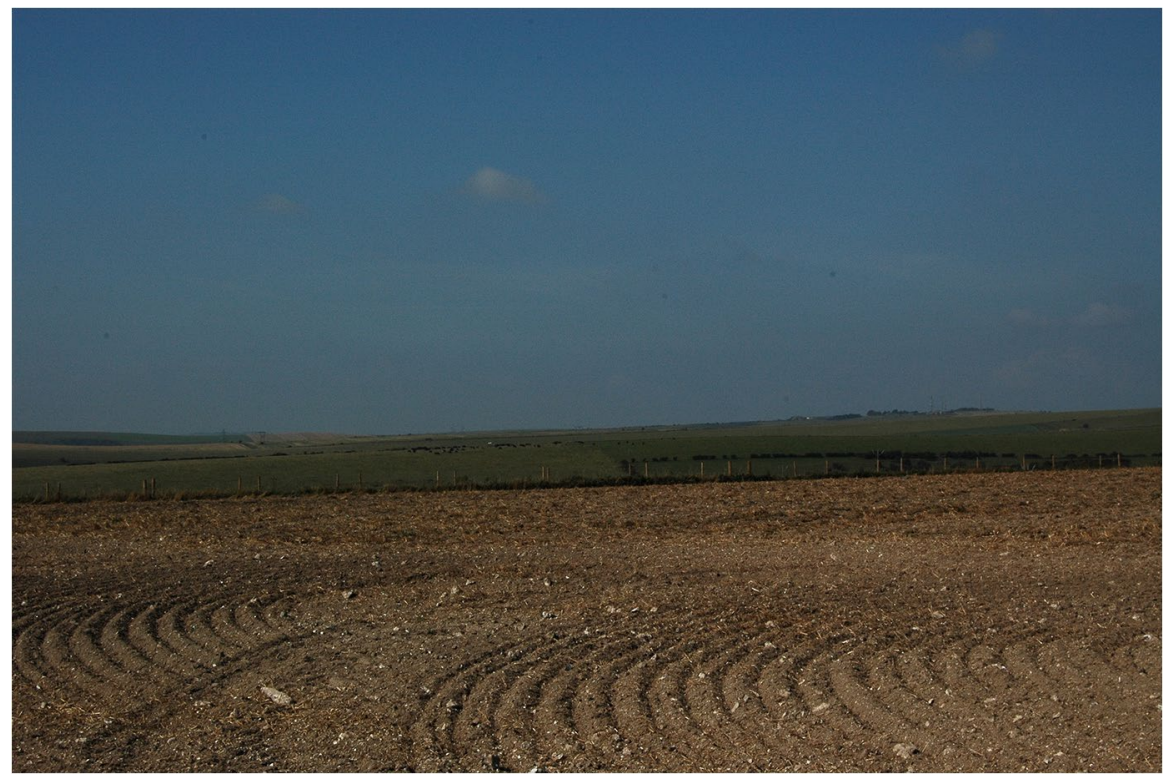

Fig. 6 A recently harvested field on the downland north of Hangleton, illustrating the occurrence of abundant nodular flint on the surface (photograph: Ben Jervis) 
the past, rooting households in space, solidifying their role in the wider community (Smith, 2010, 74). Rebuilding in stone was one element of this enfolding, petrifying status, authority and wealth in the village landscape, trapping households into cycles of repetition out of which heterogeneous lived experiences of rural domesticity emerged.

The construction of stone houses did not just represent difference but generated it. The houses represent a localised articulation of a wider shift from earth-fast to ground-set buildings around 1200 but the use of stone is extremely unusual, even locally (Gardiner, 2014b, 18-22). Stone was typically reserved for the principal buildings of the village landscape, the church and manor house, coming to be a symbol of status. Hangleton reminds us that a simple equation between stone and status neutralises stones potential (Irigaray \& Marder, 2016, 189; Cohen, 2015, 33). Stone is not homogeneous; it could be local or imported, with the situation of a community determining the availability of specific materials. It could be selected for its decorative colour, hardness or strength. It could take the form of rubble, blocks or intricately carved pieces. It could be freshly quarried or re-used from an earlier structure. The use of stone at Hangleton requires us to understand the capacities of the material in this specific context and to examine how it articulates with the emergence of community and the distribution of power.

Most of the building stone used at Hangleton is locally sourced flint. Even today, large flint nodules litter fields after ploughing whilst further material could be obtained from quarry pits (Fig. 6). More generally, quarrying was a common activity in the medieval countryside and, in some instances, tenants were obliged to provide stone from their holdings for manorial building projects (Moorhouse, 1990, 143; Cadman, 1990; Parsons, 2018). Documented works to the church at Hangleton in the thirteenth century (Fig. 7), coinciding with a change in Hangleton's lordship, suggest that re-building was a co-ordinated activity, perhaps an act of Thomas de Poynings who held the manor in the early fourteenth century. Whilst the buildings highlight the heterogeneity of the community and the lived experience of its members, the acquisition of flint, either through surface collection or quarrying, and pooling of resources to construct these buildings are suggestive of community cooperation. Flint building was a slow process, requiring time for mortar to go off and work would have to halt in heavy rain (Roberts, 1974, 85-6). At Hangleton, a mix of knapped and unworked nodules was used, suggestive of unskilled labour being employed in house construction. In contrast, the mortared walls imply the presence of a stonemason amongst the village community, the acquisition of knowledge and skill (perhaps through the erection of the church) or the employment of a professional (see Longcroft, 2006 70). Analysis of the composition of the mortars suggests the aggregates were not derived from the underlying clay with flints and may have been sourced from the beach. In the fourteenth century at nearby Wiston, sea sand was purchased for this purpose (Holden, 1963, 180). The most likely source for the aggregate is the beach at Portslade, a couple of miles to the south. It may have been purchased or collected by tenants, being carted overland to the village. Hangleton is not a coastal village but is only a couple of miles inland. This proximity afforded possibilities; it made materials accessible; landscape and community became implicated in each other. 


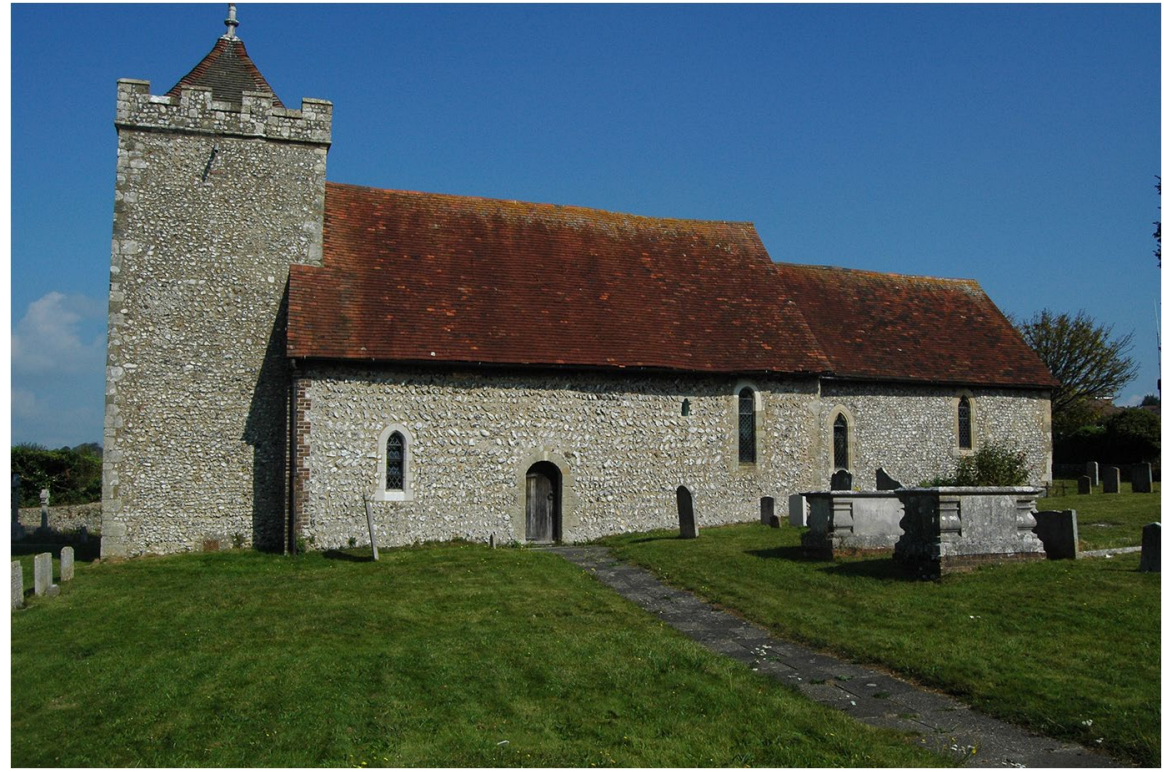

Fig. 7 The church of St Helen, Hangleton, viewed from the south. The tower was added in the early thirteenth century and the chancel (to the right) was re-built around 1300 (photograph: Ben Jervis)

The use of stone at Hangleton was not an explicit statement of meaning, but a form of difference emerging from cycles of repetition, of multi-scalar folds. We can consider the affordances of the environment itself. Flint nodules were readily brought to the surface through ploughing, whilst the chalk upland capped with heavy, flinty clay was well suited to pasture (Pelham, 1934, 132-4). The manor could profit from the high demand for wool (Pelham, 1933; Rose, 2017), and additional flint could be obtained through light quarrying of land out of cultivation, with suitable aggregates accessible on the beaches only a few miles away (Holden, 1963). The acquisition of stone and aggregate for the building of the church and, perhaps, the manor house, required labour. This could have been obtained through waged labour; in coastal Sussex, intensive arable farming was achievable through a strong reliance on waged labour (Brandon, 1971, 117), or through obligations of service, which locked the peasantry into relations of subjugation (Wickham, 2021, 10). The question of whether the lord or tenant was responsible for the erection and upkeep of houses is debated. In the countryside, it was usual for tenants to fund these works, although this could be a source of tension between lord and tenant (Slocombe, 2018; Currie 2018; Dyer, 2019). In medieval England, it was common for quarrying to be undertaken by 'direct labour' (that is under the authority of the builder) where there was such a close link between the building site and the stone (Knoop \& Jones, 1938, 26), whilst at Hangleton, surface collection was likely linked to agrarian tasks. Stone acquisition was a 'de-territorialisation' of power-in being exerted, it led to a process of gathering of people and materials with generative potential (Woodward et al., 2012, 217; Crellin, 2021). Church building was funded by the community, but 
most commonly by a smaller group of wealthier tenants and the gentry (Byng, 2017, 9; 108-11). In the early sixteenth century at Bolney, West Sussex, works to the church were undertaken by a small group of contracted masons and local labourers (Byng, 2013). The archaeological evidence from Hangleton is perhaps suggestive of a similar arrangement, with the specialist skills being contracted with labour being provided locally, although it is not possible to ascertain if this was conscripted, voluntary or waged. If obliged to provide labour to this building project, be that through construction works or the gathering of materials, this may have been given willingly as households benefitted both from improvements to their built environment and spiritually from works to the church. However, the community was involved in church building, the link between agriculture and the acquisition of building stone shows how this gathering both afforded material benefits to a community who was simultaneously being oppressed through the regime of labour and service in which they were entangled. This labour, whatever form it took, could only be drawn upon because of historical processes which trapped households into cycles of repetition through the need to maintain rights to land (Wickham, 2021, 12).

For Thomas de Poynings, or his predecessor, the stone buildings could have operated as a symbol of his ability to mobilise communal labour, as a petrifaction of strong lordship, mastery of his resources both human and non-human. The stone church, as a public building, and the stone houses, constructed of durable materials gathered from the manor, were both visual and enduring expressions of power over the community and the landscape. They are representative of a timelessness which stands in contrast to the changes in rural society brought about by the breakdown of serfdom and a commercialising economy; investment in petrification was investment in both the display and negotiation of control. Lordship on the downland and coastal plain contrasts that further north in the densely wooded Weald, where tenants typically had a greater degree of freedom (Campbell \& Bartley, 2006, 253-4; 265). A contrast between these areas was the relative abundance of stone and wood. At Hangleton, stone was abundant and could be extracted from the manor without disrupting agricultural production (indeed stone had to be removed anyway). In contrast, timber had to be imported from the dense forest of the Weald, where there was a high demand both from construction, but also the growing iron industry and from the crown and export markets (Pelham, 1928; Gardiner, 1996, 133). For the villagers, the houses were simultaneously instruments of oppression and potential. The stone was likely gathered from the fields they worked for the manor whilst they had to meet the costs of construction, yet once constructed, they provided durable and comfortable dwellings, the form of which (e.g. in terms of size) solidified their position within the community; new forms of becoming emerged from mixtures of materials predicated on the suppression, or petrification, of difference (Cohen, 2005, 34). Construction potentially strengthened community bonds, even as the erection of houses of varying size and form materialised difference. As such, they might be understood as what de Certeau (1988, 117-18) terms a 'practiced place', a site through which dominant groups could exercise power (e.g. through granting rights to the plot in which a house was built) but which offered opportunities for resistant practices and emergent difference. The house itself, then, is a territorialisation not only of materials into a built form, but also of relations of power and obligations and 
the affordances of landscape which actualised specific compositions of community, articulated through moments of repeated exploitation of resources and labour.

These houses emerged from the overlapping of multiple 'taskscapes' (Ingold, 1993) — of building, agrarian production, lordship and international trade. Sets of relations which map onto extensive space as messy entanglements but are more than that; they are generative, affective and intensive (McFadyen, 2006). This demonstrates how an intervention into assemblages is always an intervention into the middle (Stark, 2017, 25). Even a study of village formation is not a starting point in the longer history of a landscape. Here established structures of power were enfolded into building both through the sourcing of material and the siting, size and form of the houses. The landscape had capacities for generating difference, surfacing geological and environmental difference, enfolded into an established agrarian system. This created a specific, situated regime of labour, the repetition of which was territorialised, or enfolded, into these buildings both through their construction and their design.

\section{Household Economy}

Whilst not defined by it, households are intimately connected to the house eventspace. Wilk and Rathje (1982) defined the household as the smallest identifiable social unit of production, offering a bridge between the individual and society. Their generalising approach was critiqued by Hendon (1996) who emphasised the household as a location for the articulation of gendered difference through labour. It is now common for archaeologists to identify households as social units defined by activities and behaviour of co-resident groups which extend beyond the physical space of the house or plot (Allison, 1999; Brandon \& Barile, 2004, 6; Nash, 2009, 225; Pluckhahn, 2010; Carballo, 2011, 134; Douglass \& Gonlin, 2012; Beaudry, 2015, 4; Bolender \& Johnson, 2016, 66). Rather than being defined units nested within a community, households are porous collectives, entangled with other social groups, for whom spaces beyond houses are important areas of collective encounter (Anderson, 2004; Barile, 2004, 122; Battle, 2004, 43; Pluckhahn, 2010, 338; Reeves, 2015, 36). These entanglements may take the form of collaboration in agrarian or craft production, care or domestic work (e.g. Carballo, 2011, 148). Households, like communities, are not homogeneous entities (Franklin, 2020). In medieval society, for example, whilst older generations held the right to land, it was younger generations who had the capacity to enter into waged labour and benefit from the comparative financial and capital independence that this generated-a trend which boomed following the demographic shocks of the fourteenth century (De Moor \& Van Zanden, 2010). This growing labour market created opportunities for novel encounters and both social and geographic mobility. Households are sites of social production as they are themselves continually becoming; they both drive and form within external processes such as commercialisation (Wood, 2004, 210; Bolender \& Johnson, 2016, 76). Households are, therefore, both aggregations of repetition, in the form of socialisation, and generators of difference, as they are de-territorialised into relations 
beyond the home (Rees Jones, 2003, 12; Riddy, 2003, 129; Hamling \& Richardson, 2018, 7).

In medieval villages, houses and associated land divisions mark the household as a defined entity under its head, which itinerated through fiscal and legal practice. Archaeological objects show how wider encounters pulled people into other groupings. Items associated with ploughing from Building 1 at Hangleton suggest the seasonal aggregation of communities of practice. If we follow artistic depictions, spindle whorls mediated the social life of peer groups of women, who span as they socialised and watched their children play (see Standley, 2016). These groups, like houses, can be understood in terms of folds and flows, obligation, shared experiences and memory; the demands of the land and spatial proximity all worked to re-constitute them in accordance with varying temporal rhythms. This complexity is captured in disagreements over the relationship between the medieval household and the nuclear family (e.g. Razi, 1993; Schofield, 2003, 82-7; Riddy, 2003). Whilst portable objects provide hints at the various communities that the Hangleton population were a part, variability in the houses themselves is suggestive of diversity in domestic organisation. Holden (1963) suggested that Building 1, the largest house, may have been the home of the Reeve, a manorial official. The relationship between Buildings 3 and 8, both likely to have been houses, within a fenced enclosure, may suggest the presence of an extended family living as a single household (Fig. 8). Whilst the household existed as a legal and fiscal unit, it was heterogenous in its composition, having a degree of plasticity in the physical spaces which they inhabited.

The entangled household relations at Hangleton can be examined through a particular activity-brewing. A distinctive feature of the houses is the presence of ovens. These take two forms: ovens with a clay dome (Buildings 3,11), of the type typically used for baking, and more unusual features lacking a flue (Buildings $8,10 \mathrm{~B}, 12)$. These are not of uniform design, appearing to be improvisations to create enclosed hearths, typically in a separate annexe. Similar arrangements can be found in the brewhouse complex at Buckland Abbey, Devon (Allan, 2006) and Fountains Abbey, Yorkshire (Rickett \& McKerracher, 2021, 124) and have

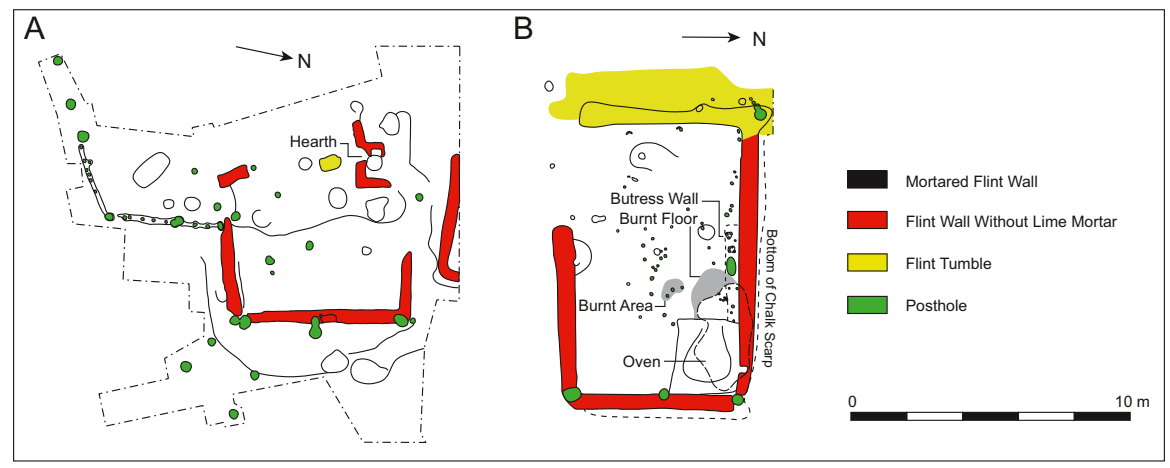

Fig. 8 Hangleton Buildings 8 and 3 (redrawn by Gethyn Long and Kirsty Harding after Holden, 1963) 
been interpreted as vat stands at Southwick, Northamptonshire (Johnston et al., 2001). Therefore, I suggest these ovens provide evidence of brewing at a scale requiring a distinctive brewhouse, rather than the use of domestic hearths. There is further circumstantial evidence for brewing; quern fragments may suggest the grinding of malt, whilst ceramic bunghole pitchers are a form commonly associated with ale (Moorhouse, 1978). Medieval agricultural communities often undertook craft production to diversify their economic base (e.g. Blanchard, 1972; Hatcher, 1974; Postles, 1992; Sapoznik, 2016; Wickham, 2021, 37).

Thanks to the work of Bennett (1996) and Mate (1998), domestic brewing has become emblematic of medieval female labour. Bennett's analysis demonstrates how women dominated brewing around 1300, with this typically being a form of supplementary 'by-work'. Because of ale's short shelf-life, it could be sold to neighbours or at the local market. Most households brewed only occasionally, effectively taking turns to supply their neighbours. The archaeological evidence from Hangleton suggests relatively intensive brewing. The situation of vat stands, or furnaces, in annexes created a spatial distinction between living space, and the domestic hearth, and a specialised but accessible, brewing space. The interconnectedness between these spaces suggests regular brewing which took place around other activities such as childcare or cooking.

Bennett $(1996,1997)$ proposes that women dominated brewing because of its low economic value. She argues that within a patriarchal economy and system of power, female labour was relegated to the performance of economically marginal tasks, supplementary to household income. Her analysis presents a more complex picture than a simple binary division of labour, demonstrating how marital status, place of residence and wealth all contributed to the scale and intensity of brewing, its profitability and contribution to household income. Whilst the bulk of the agricultural workforce was male, women were variously engaged in elements of agricultural labour alongside domestic tasks (Whittle, 2013, 317). Gendered work varied seasonally, with there being demands on female labour at harvest-time, for example (Flather, 2013, 351). In this regard, gendered difference was not static but cyclical (see also Cohen, 2005, 5), predicated on patterns of repetition but opening female bodies to new experiences which took them beyond any 'domestic sphere' they may have inhabited.

Tracing an overly simplified gendered division of labour onto space, with men occupying spaces beyond the home and women domestic space, neutralises labour's potential to be generative of gendered difference. We become locked into a cycle of repetition of ascribed gender roles, trapped into binary distinctions which supress the surfacing of difference, a contrast in scale whereby women undertake the 'micro' domestic tasks and men are the driving force behind macroeconomic growth, building in an inherent androcentric bias into the interpretation of space (see also Goldberg, 1999; Spencer-Wood, 1999; Nash, 2009, 206). Patriarchal authority, service obligations and domestic knowledge can all be understood as folds, replicated through practice and materialised, to a certain degree, in domestic architecture. We cannot ignore this subjective politics of oppression, but we can suspend it if we focus on lived experience (Pluckhahn, 2010; Woodward 
et al., 2012, 217), on labour as an intensity or assemblage, to shift focus towards what is generated-what passes through the fold.

Domestic knowledge would have passed between generations, for example, through imitative play (Hanawalt, 1986, 182-3). This process of socialisation and knowledge transfer was a mechanism for repetition, the surfacing of embodied knowledge through day-to-day domestic 'happenings' or what Woodward et al., $(2010,278)$ term repetitive 'processes of banality'. This creates a perspective of the household as timeless and persistent. The biography of the Hangleton houses is suggestive of something different, of improvisation, adaptation and change, a plasticity emerging from the unpredictability of encounter (Wood, 2004, 210). Given the centrality of ale to medieval diet, it is probable that domestic-scale brewing took place in the timber structures at Hangleton, probably suspending vessels over the hearth which was the centrepiece of the home. The stone houses represent an investment in the intensification of production. This is unlikely to have been speculative, instead being a conscious and deliberate response to economic opportunity. As McFadyen $(2007,122)$ reminds us, architecture was constructed with the knowledge of 'going somewhere', that somewhere being a mix of intended destinations and unexpected affect. Yet, brewing remained rooted in domestic space. Whilst the design of these houses creates specialised spaces of production, the boundary was permeable. Brewing was both simultaneously inside and outside of the domestic, being a route through which households could become de-territorialised into wider webs of relations generative of difference. Brewing itself was generative of difference. Following Hamilakis $(2017,177)$, we can reflect on the role of these spaces of production in the emergence of a sensorial assemblage of brewing, as locales in which ingredients are transformed into ale, in which fuel is transformed to ash and brewer and ingredients and tools emerge together, building experience and memories distinct to this 'event-space'. These spaces are, of course, indicative of economic and domestic transformation but in thinking through domestic space as intensity they become more than that, being generative of a distinct, and likely gendered, sensorium of brewing.

In modern economic terms, we might consider brewing at Hangelton in terms of scalability, domestic level production being scaled up to supply new markets. These markets emerged from a process of commercial growth through the twelfth-thirteenth centuries. It did not take the form of a teleological progression towards modern capitalism (Cohen, 2005, 19-20; Howell, 2010, 300-301; Jervis, 2018, 2022; Wickham, 2021, 15), but surfaced as a patchwork of happenings or intensities. By mapping the relations required for brewing, we can see how the capacities, or affordances, for the community to brew were distributed across wide networks and the landscape (see also Handsmann, 2018). Brewing becomes more than a linear process, but a dispersed assemblage of barley, wood, flint, fish, water, animals, plants and buildings. It was not a uniformly experienced form of by-work but a situated emergence, generative of lived and sensorial experience, memory and skill shaped by geological, human and environmental pasts and formative of contextually gendered and open-ended bodies.

The environmental context of village communities pulled them into wider networks (Dyer, 2007b, 23) as the market came to provide a mechanism for obtaining 
services or resources not available within the manor. The principal grain cultivated in Sussex was wheat. Barley was less profitable; high yields could be obtained in this region (Brandon, 1962, 64; see also Campbell, 2000, 286). Brewing was entangled within an agrarian economy split between tenant and demesne (manorial) husbandry, in which environment and economic forces shaped agrarian decisions. The productivity of barley cultivation created opportunities for intensive brewing, adding value to the cultivation of a less lucrative crop. Brewing also required the high quantities of fuel, placing demands on managed woodlands which were under high demand from growing towns and cities, both in England and across the channel (Galloway et al., 1996; Gardiner, 1996; Pelham, 1928). Where fuel demands exceeded what could be sourced locally, it had to be obtained from the market, drawing households into a commercial network extending well beyond the village. These supply-side networks are mirrored when we explore the capacity for demand at Hangleton. The ovens are suggestive of households being equipped to produce large quantities of surplus ale to supply a market beyond the village community.

The evidence from Hangleton may relate to Bennett's findings that brewing became increasingly specialised through the fourtheenth century, with households choosing to invest in production (Bennett, 1996, 48-50). In Sussex, Mate (1998, 59) demonstrates that, as elsewhere, brewing became increasingly specialised with a smaller number of households brewing more intensively. It was usual for household brewing to serve the needs of the immediate community; however, there are instances of brewing for nearby markets and the evidence may simply reflect brewing for the needs of the village community. However, there is evidence for ale to be traded through local markets. At Stoke Fleming, Devon, for example, court records are suggestive of brewing for the market in the nearby port of Dartmouth (Postles, 1992, 136), with the organisation of brewing across the county varying in relation to local commercial, agrarian and administrative factors. Elsewhere in England, there is increasing evidence for the wider trade in ale through local markets in the period after the Black Death as people drank more ale, but were supplied by fewer producers, although the exact scale of this trade is unclear (Bennett, 1996, 47). At Hangleton, such markets may have included the town of Shoreham, 4.5 miles to the west; the fishing village of Brighton, 4 miles to the east and the coastal, rural communities in the adjacent manors of Aldrington and Portslade (see Gardiner, 2001). These manors had a mix of fertile soils in the downland scarp and stonier marine gravels, less favourable to arable cultivation. Areas of saltmarsh and meadow provided grazing (Brookfield, 1952; Baker, 1964; Brandon, 1971, 116; Campbell, 2000, 284). These communities had ready access to the sea, fertile agricultural land and good quality pasture, giving them a different household economy to the downland manor at Hangleton. Arable production could be more intensive, whilst the communities would have been engaged in the catching and processing of fish and, as the mollusc evidence from Hangleton suggests, the harvesting of oysters. Within this context, the ovens may represent the actualisation of capacities within the wider landscape for economic specialisation; Hangleton perhaps occupied a niche from which specifically situated forms of household economy could emerge.

As Tsing $(2015,38)$ argues, scaling is not a neutral and smooth process. It is not repetition, but an intensification of flows; they move more rapidly, absorb more 
resources and generate something different. Tsing argues that modern capitalism 'salvages' elements of household economies, instrumentalising them in alienated regimes of production. Brewing remained rooted in the home, but extended beyond its physical boundaries. It entangled households into a wider commercial regime. Whereas brewing in some households and communities was by-work, here it had the potential to become more. Households were participants in economic intensification, demanding more resources such as fuel, shaping agrarian production and placing demand on commodities. This is not to argue for rural women to be placed at the vanguard of economic development, but to demonstrate that commercialisation was formed of mixtures of repetition and difference. Commerce drew women out of the home and into the market, both as consumers and vendors; it had implications for the forms that domestic labour might take (Phillippi, 2018). It allowed for worlds to expand beyond the home or village; it smoothed domestic spaces, created potential for new forms of domesticity and situated gendered becoming to emerge. This is not to say that these brewing women were enfranchised economic actors; patriarchal power persisted in the organisation of manor and household, but, as Catlin argues in relation to the Devon longhouse, the home was more than a site of patriarchal power. The home was not a site of endless repetition, but of productive difference.

\section{From Settlement Space to Intensive Community}

Understanding rural communities as intensities reveals difference. Houses and villages become more than extensive spaces, being locales of de-territorialisation through which inhabitants are caught up in regimes of difference and repetition. Whilst studies of spatial grammar have linked the study of buildings to understanding of identity, domesticity and society, these also risk drawing us into neutralising, binary formulations. Studies of rural settlements have increasingly stressed diversity, critiquing generalisations by revealing alternative types of community. Similar trends can be seen in the study of the form and material of medieval buildings and material culture assemblages. The approach sketched here understands rural communities as negotiations of difference whilst acknowledging the apparent stasis and homogeneity brought about by material, legal and customary formations. An emphasis on becoming through practice equips us to understand how bodies emerged in spite of the texts, structures and materials which sought to supress them (Cohen, 2005, 34). Intensity draws us beyond the home, into the future and into the generative space of difference (see also McFadyen, 2007). By thinking in this way, we are able to break-out of a disabling gender binary to understand how domesticity, commercialisation, agricultural production, landscape management and other activities were implicated in the patchwork of intensities which were medieval-lived experiences.

Intensity invites us to do rural archaeology differently. By fixing our gaze on practice and entanglement, we can map communities beyond the confines of the settlement. This is not to neglect key themes of settlement formation, rural economy and household architecture, but to imagine them differently. Rather than seeking to classify difference in terms of what settlements or buildings lack (nucleation, 
property boundaries, spatial divisions), we can use our evidence to reveal diverse processes of rural becoming. This requires us to pay attention to the ways in which materials de-territorialise settlements beyond their physical sites, to think about the demands that landscapes or resources place on communities and how these intersect with the enfolded customs of obligation and reliance at the heart of medieval rural society. Doing so releases us from the perpetual cycle of repetition to understand the constitution of emergent difference in past societies.

\section{Author Contribution N/A.}

Data Availability N/A.

Code Availability N/A.

\section{Declarations}

Conflict of Interest The author declares no competing interests.

Open Access This article is licensed under a Creative Commons Attribution 4.0 International License, which permits use, sharing, adaptation, distribution and reproduction in any medium or format, as long as you give appropriate credit to the original author(s) and the source, provide a link to the Creative Commons licence, and indicate if changes were made. The images or other third party material in this article are included in the article's Creative Commons licence, unless indicated otherwise in a credit line to the material. If material is not included in the article's Creative Commons licence and your intended use is not permitted by statutory regulation or exceeds the permitted use, you will need to obtain permission directly from the copyright holder. To view a copy of this licence, visit http://creativecommons.org/licen ses/by/4.0/.

\section{References}

Alcock, N. (2015). The development of the vernacular house in south-west England, 1500-1700. In J. Allan, N. Alcock and D. Dawson (Eds.), West Country Households 1500-1700 (pp. 9-34). Boydell (Society for Post-Medieval Archaeology Monograph 9).

Allan, J. (2006). The excavation of a brewhouse at Buckland Abbey in 2005. Proceedings of the Devon Archaeological Society, 64, 241-265.

Allison, P.M. (1999). Introduction. In P.M. Allison (Ed.), The Archaeology of Household Activities (pp. 1-18). Routledge. https://doi.org/10.4324/9780203014929

Anderson, N. (2004). Finding the space between spatial boundaries and social dynamics: The archaeology of nested households. In K.S. Barile and J.C. Brandon (Eds.), Household Chores and Household Choices. Theorizing the Domestic Sphere in Historical Archaeology (pp. 109-120). University of Alabama Press. https://muse.jhu.edu/book/6640

Austin, D. and Thomas, J. (1990). The 'proper study' of medieval archaeology. A case study. In D. Austin and L. Alcock (Eds.), From the Baltic to the Black Sea. Studies in Medieval Archaeology (pp. 19-27). Routledge.

Bailey, M. (2014). The decline of serfdom in late medieval England: From bondage to freedom. Boydell.

Baker, A. R. H. (1964). Some evidence of a reduction in the acreage of cultivated lands in Sussex during the early fourteenth century. Sussex Archaeological Collections, 104, 1-5.

Barile, K.S. (2004). Hegemony within the household; the perspective from a South Carolina plantation. In K.S. Barile and J.C. Brandon (Eds.), Household Chores and Household Choices. Theorizing the 
Domestic Sphere in Historical Archaeology (pp. 121-37). University of Alabama Press. https:// muse.jhu.edu/book/6640

Battle, W. (2004). A space of our own: Redefining the enslaved household at Andrew Jackon's Hermitage Plantation. In K.S. Barile and J.C. Brandon (Eds.), Household Chores and Household Choices. Theorizing the Domestic Sphere in Historical Archaeology (pp. 33-50). University of Alabama Press. https://muse.jhu.edu/book/6640

Beaudry, M. (2015). Households beyond the house: On the archaeology and materiality of historical households. In K. R. Fogle, J. A. Nyman, \& M. C. Beaudry (Eds.), Beyond the Walls: New Perspectives on the Archaeology of Historical Households (pp. 1-22). University of Florida Press.

Beck, A. S. (2017). Temporalising the house: Exploring alternative perspectives on time and the archaeological record within Danish settlement archaeology. Danish Journal of Archaeology, 6(1), 67-83.

Beck, A. S. (2018). Revisiting the Trelleborg house: A discussion of house types and assemblages. Norwegian Archaeological Review, 51(1-2), 142-161.

Bennett, J. (1996). Ale, beer and brewsters in England: Women's work in a changing world, 1300-1600. Oxford University Press.

Bennett, J. (1997). Confronting continuity. Journal of Women's. History, 9(3), 73-94.

Bennett, J. (2010). Vibrant matter. Duke University Press.

Bennett, J. and Karras, R. (Eds.). (2013). The Oxford handbook of women and gender in medieval Europe. Oxford University Press.

Blanchard, I. (1972). The miner and the agricultural community in late medieval England. Agricultural History Review, 20, 93-106.

Bolender, D. J., \& Johnson, E. D. (2016). Reassembling the household for Icelandic archaeology: A contribution to comparative political economy. Post-Medieval Archaeology, 52(1), 65-83.

Bourdieu, P. (1977). Outline of a theory of practice. Cambridge University Press.

Braidotti, R. (1994). Nomadic subjects. Columbia University Press.

Braidotti, R. (2013). The posthuman. Polity Press.

Brandon, P. (1962). Arable farming in a Sussex scarp-foot parish during the late Middle Ages. Sussex Archaeological Collections, 100, 60-72. https://doi.org/10.5284/1085812

Brandon, J.C. and Barile, K.S. 2004, Introduction: Household chores; or, the chore of defining the household. In K.S. Barile and J.C. Brandon (Eds.), Household Chores and Household Choices. Theorizing the Domestic Sphere in Historical Archaeology (pp. 1-14). University of Alabama Press. https://muse.jhu.edu/book/6640

Brandon, P. (1971). Demesne arable farming in coastal Sussex during the later Middle Ages, The Agricultural History Review, 19 (2), 113-34 https://www.jstor.org/stable/40273783

Briggs, C., Forward, A., Jervis, B., \& Tompkins, M. (2019). People, possessions and domestic space in the late medieval escheators' records. Journal of Medieval History, 45(2), 146-161. https://doi.org/ $10.1080 / 03044181.2019 .1593624$

Brookfield, H. C. (1952). The estuary of the Adur. Sussex Archaeological Collections, 90, 153-163. https://doi.org/10.5284/1086388

Bütser, L. (2021). Iron Age mnemonics: A biographical approach to dwelling in later prehistoric Britain. Cambridge Archaeological Journal, 31(4), 61-674 https://doi.org/10.1017/S0959774321000263

Byng, G. (2013). The construction of the tower at Bolney Church. Sussex Archaeological Collections, $151,101-113$.

Byng, G. (2017). Church building and society in the later Middle Ages. Cambridge University Press.

Cadman, G. (1990). Recent excavations on Saxon and medieval quarries in Raunds, Northamptonshire. In D. Parsons (Ed.), Stone. Quarrying and Building in England AD 43-1525 (pp. 197-206). Phillimore.

Campbell, B. (2000). English seigniorial agriculture 12050-1450. Cambridge University Press.

Campbell, B., \& Bartley, K. (2006). England on the eve of the Black Death: An atlas of lay lordship and wealth, 1300-49. Manchester University Press.

Carballo, D. M. (2011). Advances in the household archaeology of highland Mesoamerica. Journal of Archaeological Research, 19, 133-189. https://doi.org/10.1007/s10814-010-9045-7

Catlin, K. (2016). Re-examining medieval settlement in the Dartmoor landscape. Medieval Settlement Research, 31, 36-45. https://doi.org/10.5284/1059089

Claridge, J., \& Langdon, J. (2011). Storage in medieval England: The evidence from purveyance accounts, 1295-1349. THe Economic History Review, 64(4), 1242-1265. https://doi.org/10.1111/j. 1468-0289.2010.00564.x

Cohen, J. J. (2005). Medieval identity machines. University of Minnesota Press. 
Cohen, J. J. (2015). Stone. University of Minnesota Press.

Crellin, R. (2020). Change and archaeology. Routledge.

Crellin, R. (2021). Posthumanist power. In R. Crellin, C. Cipolla, L. Montgomery, O. Harris and S. Moore (eds), Archaeological Theory in Dialogue. Situating Relationality, Ontology, Posthumanism and Indigenous Paradigms (p.115-32). Abingdon: Routledge.

Currie, C. (2018). Why historians believe that customary tenants normally paid for their own buildings: A reply to Pamela Slocombe. Vernacular Architecture, 49, 38-43.

De Certeau, M. (1988). The practice of everyday life (Translated by Steven Rendall). University of California Press.

De Moor, T., \& Van Zanden, J. L. (2010). Girl power: The European marriage pattern and labour markets in the North Sea region in the late medieval and early modern period. The Economic History Review, 63(1), 1-33. https://doi.org/10.1111/j.1468-0289.2009.00483.x

DeLanda, M. (2005). Space: Extensive and intensive, virtual and actual. In I. Buchanan \& G. Lambert (Eds.), Deleuze and Space (pp. 80-88). Edinburgh University Press.

DeLanda, M. (1997). A thousand years of non-linear history. Swerve.

DeLanda, M. (2016). Assemblage theory. Edinburgh University Press.

Deleuze, G. (1968). (2001 edition). Difference and Repetition. Continuum.

Deleuze, G. and Guattari, F. (1983) [2004 edition]. Anti-Oedipius. Bloomsbury.

Deleuze, G. and Guattari, F. (1987) [2013 edition]. A thousand plateaus. Bloomsbury.

Douglass, J.G. and Gonlin, N. (2012). The household as analytical unit: Case studies from the Americas. In J.G. Douglass and N. Gonlin (Eds.), Ancient Households of the Americas. Conceptualizing What Households Do (pp. 1-44). University Press of Colorado. https://www-jstor-org.abc.cardiff. ac.uk/stable/j.ctt4cgr80

Dyer, C. (1994). The English medieval village community and its decline. Journal of British Studies, 33(4), 407-429. https://doi.org/10.1086/386063

Dyer, C. (2007a). The ineffectiveness of lordship in England, 1200-1400. Past \& Present, 195(Supp. 2), 69-86. https://doi.org/10.1093/pastj/gtm022

Dyer, C. (2007b). Were late medieval English villages 'self-contained'? In C. Dyer (Ed.), The Self-Contained Village? The Social History of Rural Communities 1250-1900 (pp. 6-27). University of Hertfordshire Press.

Dyer, C. (2013). Living in peasant houses in late medieval England. Vernacular Architecture, 44, $19-27$. https://doi.org/10.1179/0305547713Z.00000000012

Dyer, C. (2019). A comment on rural tenants and their buildings in the later middle ages. Vernacular Architecture, 50, 53-56.

Eisenman, P. (1991). Unfolding events: Frankfurt Rebstock and the possibility of a new urbanism. In J. Geib \& S. Kohso (Eds.), Unfolding Frankfurt (pp. 8-17). Ernst \& Sohn.

Flather, A. (2013). Space, place and gender: The sexual and spatial division of labour in the early modern household. History and Theory, 52, 344-360. https://doi.org/10.1111/hith.10673

Franklin, M. (2020). Enslaved household variability and plantation life and labor in colonial Virginia. International Journal of Historical Archaeology, 24, 115-155. https://doi.org/10.1007/ s10761-019-00506-X

Freedman, P. (2001). Georges Duby and the medieval peasantry. The Medieval History Journal, 4(2), 259-71. https://doi.org/10.1177/097194580100400205

French, K. (2005). The seat under our lady: Gender and seating in late medieval English parish churches. In V. Chieffo Raguin and S. Stanbury (Eds.), Women's Space. Patronage, Place and Gender in the Medieval Church (pp. 141-60). State University of New York Press.

Galloway, J., Keene, D., \& Murphy, M. (1996). Fuelling the city: Production and distribution of firewood and fuel in London's region, 1290-1400. Economic History Review, 49(3), 447-472. https://doi. org/10.1111/j.1468-0289.1996.tb00577.x

Gardiner, M. (1996). The geography and peasant rural economy of the eastern Sussex High Weald, 13001420. Sussex Archaeological Collections, 134, 125-139. https://doi.org/10.5284/1086220

Gardiner, M. (2000). Vernacular buildings and the development of the later medieval domestic plan. Medieval Archaeology, 44, 159-179. https://doi.org/10.1179/med.2000.44.1.159

Gardiner, M. (2001). Medieval fishing and settlement on the Sussex coast. Medieval Settlement Research Group Annual Report, 16, 6-7.

Gardiner, M. (2014b). An archaeological approach to the development of the late medieval peasant house. Vernacular Architecture, 45, 16-28. https://doi.org/10.1179/0305547714Z.00000000022 
Gardiner, M. (2008). Buttery and pantry and their antecedents: Idea and architecture in the English medieval house. In M. Kowaleski and J. Goldberg (Eds.), Medieval Domesticity. Home, Housing and Household in Medieval England (pp. 37-65). Cambridge University Press.

Gardiner, M. (2014a). The distribution and adoption of the byre-house (longhouse) in late medieval Britain. In I. Boháčová, and P. Sommer (Eds.), Středověká Evropa v Pohybu. K Poctě Jana Klápště (pp. 145-62). Institute of Archeology AS CR, Prague.

Gilchrist, R. (1994). Gender and material culture: The archaeology of religious women. Routledge.

Gilchrist, R. (1999). Gender and archaeology: Contesting the past. Routledge.

Gilchrist, R. (2012). Medieval life. Archaeology and the lifecourse. Boydell.

Giles, K. (2000). An archaeology of social identity: Guildhalls in York, c.1350-1630. BAR British Series 315.

Goldberg, P. (2011). Space and gender in the medieval English house. Viator, 42(2), 205-232. https://doi. org/10.1484/J.VIATOR.1.102250

Goldberg, M.Y. (1999). Spatial and behavioural negotiation in classical Athenian city houses. In P.M. Allison (Ed.), The Archaeology of Household Activities (pp. 142-61) Routledge. https://doi.org/10. 4324/9780203014929

Grenville, J. (2008). Urban and rural houses and households in the late Middle Ages: A case study form Yorkshire. In M. Kowaleski and J. Goldberg (Eds.), Medieval Domesticity. Home, Housing and Household in Medieval England (pp. 92-123). Cambridge University Press.

Hamilakis, Y. (2017). Sensorial assemblages: Affect, memory and temporality in assemblage thinking. Cambridge Archaeological Journal, 27(1), 169-182.

Hamling, T., \& Richardson, C. (2018). A day at home in early modern England. Yale University Press.

Hanawalt, B. (1986). The ties that bound. Peasant families in medieval England. Oxford University Press.

Handsmann, R. (2018). Survivance strategies and the materialities of Mashantucket Pequot labour in the later $18^{\text {th }}$ century. Historical Archaeology, 52, 51-69. https://doi.org/10.1007/s41636-017-0076-5

Harris, O. (2014). (Re)assembling communities. Journal of Archaeological Method and Theory 21 (1), 76-97.

Hatcher, J. (1974). Myths, miners and agricultural communities. Agricultural History Review, 22, 54-61.

Heley, J., \& Jones, L. (2012). Relational rurals: Some thoughts on relating things and theory in rural studies. Journal of Rural Studies, 28, 208-217. https://doi.org/10.1016/j.jrurstud.2012.01.011

Hendon, J. (1996). Archaeological approaches to the organisation of domestic labor: Household practice and domestic relations. Annual Review of Anthropology, 25, 45-61. https://doi.org/10.1146/annur ev.anthro.25.1.45

Hilton, R. (1990). Class conflict and the crisis of feudalism. Verso.

Hilton, R. (1973). Bond men made free: Medieval peasant movements and the English rising of 1381. Tempus.

Holden, E. (1963). Excavations at the deserted medieval village of Hangleton. Part 1. Sussex Archaeological Collections, 101, 51-81. https://doi.org/10.5284/1085773

Howell, M. (2010). Commerce before capitalism in Europe, 1300-1600. Cambridge University Press.

Hurst, J., \& Hurst, G. (1964). Excavations at the deserted medieval village of Hangleton. Part II. Sussex Archaeological Collections, 102, 94-142. https://doi.org/10.5284/1086027

Ingold, T. (1993). The temporality of the landscape. World Archaeology, 25(2), 152-74. https://doi.org/ $10.1080 / 00438243.1993 .9980235$

Irigaray, L., \& Marder, M. (2016). Through vegetal being. Columbia University Press.

Jervis, B. (2018). Consumption and the 'social self' in medieval southern England. Norwegian Archaeological Review, 50(1), 1-29. https://doi.org/10.1080/00293652.2017.1326978

Jervis, B. (2019). Assemblage thought and archaeology. Routledge.

Jervis, B. (2022). Becoming through milling: Challenging linear narratives in medieval England. Cambridge Archaeological Journal. Advance Online Publication https://doi.org/10.1017/S095977432 1000548.

Johnson, M. (2013). What do medieval buildings mean? History and Theory, 52(3), 380-399. https://doi. org/10.1111/hith.10675

Johnson, M. (1993). Housing culture. Traditional housing in an English landscape. UCL Press.

Johnston, A. G., Bellamy, B., \& Forster, P. J. (2001). Excavations at Southwick, Northamptonshire, 1996. Northamptonshire Archaeology, 29, 129-160.

Jones, R. (2010). The village and the butterfly: Nucleation out of chaos and complexity. Landscapes, 11(1), 25-46. https://doi.org/10.1179/lan.2010.11.1.25 
Jones, J. P., Woodward, K., \& Marston, S. (2007). Situating flatness. Transactions of the Institute of British Geographers, 32, 264-276. https://doi.org/10.1111/j.1475-5661.2007.00254.x

Jones, R. and Page, M. (2006). Medieval villages in an English landscape: Beginning and ends. Windgather Press.

Knoop, D., \& Jones, G. P. (1938). The English medieval quarry. The Economic History Review, 9(1), 17-37.

Lardreau, G. and Duby, G. (1987). Dialogues avec Georges Duby. Petits Platons.

Longcroft, A. (2006). Medieval clay-walled houses: A case study from Norfolk. Vernacular Architecture, 37, 61-74. https://doi.org/10.1179/174962906X158264

Marín-Aguilera, B. (2021). Subaltern debris: Archaeology and marginalized communities. Cambridge Archaeological Journal 31 (4), 565-580 https://doi.org/10.1017/S0959774321000068

Mate, M. (1992). The economic and social roots of medieval popular rebellion: Sussex in 1450-51. Economic History Review, 45(4), 661-676.

Mate, M. (1998). Daughters, wives and widows after the black death. Women in Susssex 1350-1535. Boydell.

McFadyen, L. (2006). Material culture as architecture: Neolithic long barrows in southern Britain. Journal of Iberian Archaeology, 8, 91-102.

McFadyen, L. (2007). Mobile spaces of Mesolithic Britain. Home Cultures, 4(2), 117-128. https://doi. org/10.2752/174063107X208984

Mileson, S. (2015). People and houses in south Oxfordshire, 1300-1650. Vernacular Architecture, 46, 8-25. https://doi.org/10.1080/03055477.2015.1123417

Moorhouse, S. (1978). Documentary evidence for the uses of medieval pottery: An interim statement. Medieval Ceramics, 2, 3-21.

Moorhouse, S. (1990). The quarrying of stone roofing slates and rubble in West Yorkshire during the Middle Ages. In D. Parsons (Ed.) Stone. Quarrying and Building in England AD 43-1525 (pp. 126-46). Phillimore.

Müller, M. (2007). A divided class? Peasants and peasant communities in late medieval England. Past \& Present, 195(Supp. 2), 115-131. https://doi.org/10.1093/pastj/gtm025

Müller, M. (2013). Peasant women, agency and status in mid- thirteenth- to late fourteenth-century England: Some re-considerations. In C. Beattie \& M. F. Stevens (Eds.), Married Women and the Law in premodern Northwest Europe (pp. 91-113). Boydell.

Musson, R. (1955). A thirteenth-century dwelling at Bramble Bottom, Eastbourne. Sussex Archaeological Collections, 93, 157-170.

Nail, T. (2019). Kinopolitics: Borders in motion. In R. Braidotti and S. Bignall (Eds.), Posthuman Ecologies. Complexity and Process After Deleuze (pp. 183-204). Rowman \& Littlefield.

Nash, D. J. (2009). Household archaeology in the Andes. Journal of Archaeological Research, 17, 205-261.

Olson, S. (2016). Women's place and women's space in the medieval village. In A. Classen (ed), Rural Space in the Middle Ages and Early Modern Age. The Spatial Turn in Premodern Studies (pp. 209-26). De Gruyter. https://doi.org/10.1515/9783110285420.209

Parsons, D. (2018). Quarrying and extractive industries. In C. Gerrard and A. Gutierrez (Eds.), The Oxford Handbook of Later Medieval Archaeology in Britain. Oxford University Press. https://doi. org/10.1093/oxfordhb/9780198744719.013.20

Pelham, R. A. (1928). Timber exports from the Weald during the fourteenth century. Sussex Archaeological Collections, 69, 170-182. https://doi.org/10.5284/1086484

Pelham, R. A. (1933). The exportation of wool from Sussex in the late thirteenth century. Sussex Archaeological Collections, 74, 131-139. https://doi.org/10.5284/1086261

Pelham, R. A. (1934). The distribution of sheep in Sussex in the early fourteenth century. Sussex Archaeological Collections, 75, 128-135. https://doi.org/10.5284/1086249

Phillippi, B. (2018). Muffled but not mute. Historical Archaeology, 52, 113-124. https://doi.org/10.1007/ s41636-018-0089-8

Phillips, K. (Ed.). 2016. A cultural history of women in the Middle Ages. Bloomsbury.

Platt, C. (2016). The archaeology of the peasant land market in pre-plague England c AD 1290-1350: A way forward. Medieval Archaeology, 60(20), 300-10. https://doi.org/10.1080/00766097.2016. 1221244

Pluckhahn, T. J. (2010). Household archaeology in the southeastern United States: History, trends and challenges. Journal of Archaeological Research, 18, 331-385. https://doi.org/10.1007/ s10814-010-9040-Z 
Postles, D. (1992). Brewing and the peasant economy: Some manors in late medieval Devon. Rural History, 3(2), 133-144. https://doi.org/10.1017/S095679330000306X

Quinney, A. (1999). Hall or chamber? That is the question. The use of rooms in post-conquest houses. Architectural History, 42, 24-46. https://doi.org/10.2307/1568703

Quirós-Castillo, J. A., \& Tejerizo García, C. (2020). Filling the gap: Peasant studies and the archaeology of medieval peasantry in light of the northern Iberian evidence. Journal of Agrarian Change, 21(2), 377-395. https://doi.org/10.1111/joac.12393

Razi, Z. (1993). The myth of the immutable English family. Past \& Present, 140, 3-44. https://doi.org/10. 1093/past/140.1.3

Rees Jones, S., Riddy, F., Beattie, C., Carpenter, C., Holford, M., McClure, L., Williams, S., Rimmer, J., Goldberg, J., Hamblen, B., Davis, I., Moss, R., Tai, W., Kane, B., \& MacLean, K. (2007). The later medieval English urban household. History Compass, 5(1), 112-158. https://doi.org/10.1111/j. 1478-0542.2006.00364.x

Rees Jones, S. (2003). The public household and political power. In S. Rees Jones, C. Beattie and A. Maslakovic (Eds.), The Medieval Household in Christian Europe (pp. 11-18). Brepols. https://doi. org/10.1484/M.IMR-EB.6.09070802050003050202000801

Rees Jones, S. (2008). Building domesticity in the city: English urban housing before the Black Death. In M. Kowaleski and J. Goldberg (Eds.), Medieval Domesticity. Home, Housing and Household in Medieval England (pp. 66-91). Cambridge University Press.

Rees Jones, S. (2013). Public and private space and gender in medieval Europe. In J. Bennett and R. Karras (Eds.), The Oxford Handbook of Women and Gender in Medieval Europe. Oxford University Press. https://doi.org/10.1093/oxfordhb/9780199582174.013.023

Reeves, M. (2015). Scalar analysis of early nineteenth-century household assemblages: Focus on communities of the North Atlantic. In K.R. Fogle, J.A. Nyman and M.C. Beaudry (Eds.), Beyond the Walls: New Perspectives on the Archaeology of Historical Households (pp. 23-46). University of Florida Press. .abc.cardiff.ac.uk/https://doi.org/10.2307/j.ctvx074hg

Richardson, A. (2003). Gender and space in English royal palaces c. 1160-c. 1547: A study in access analysis and imagery. Medieval Archaeology, 47, 131-165. https://doi.org/10.1179/med.2003.47.1. 131

Rickett, R., \& McKerracher, M. (2021). Post-Roman and medieval drying kilns. Archaeopress Access Archaeology.

Riddy, F. (2003). The moral household. In S. Rees Jones, C. Beattie and A. Maslakovic (Eds.), The medieval household in Christian Europe (pp. 127-35). Brepols. https://doi.org/10.1484/M.IMR-EB.6. 09070802050003050202000801

Rippon, S., \& Morton, B. (2020). Review of medieval settlement research 2007-16. Medieval Settlement Research, 35, 1-13.

Rippon, S. (2008). Beyond the medieval village. The diversification of landscape character in Southern Britain. Oxford University Press. https://doi.org/10.1093/acprof:oso/9780199203826.001.0001

Roberts, E. (1974). Totternhoe stone and flint in Hertfordshire churches. Medieval Archaeology, 18, 66-89. https://doi.org/10.1080/00766097.1974.11735365

Rose, S. (2017). The wealth of England: The medieval wool trade and its political importance. Oxbow. https://doi.org/10.2307/j.ctvh1dss5

Salter, E. (2006). Cultural creativity in the early English Renaissance. Popular culture in town and county. Palgrave MacMillan.

Sapoznik, A. (2016). Rural industry and the peasant agrarian economy: A study of the iron industry in medieval England. In J. P. Bowen \& A. T. Brown (Eds.), Custom and Commercialisation in English Rural Society: Revisiting Tawney and Postan (pp. 36-50). Hertfordshire University Press.

Schofield, P. (2003). Peasant and community in medieval England, 1200-1500. Palgrave.

Slocombe, P. (2018). 'To beg a tree and tarry his pleasure to assign it to me' - The roles of lords, landlords and tenants in house building and improvement. Vernacular Architecture, 49, 32-37.

Smith, S. (2007). Women and power in the late medieval English village: A reconsideration. Women's History Review, 16(3), 311-321. https://doi.org/10.1080/09612020601022097

Smith, S. (2010). Houses and communities: Archaeological evidence for variation in medieval peasant experience. In C. Dyer \& R. Jones (Eds.), Deserted Villages Revisited (pp. 64-84). University of Hertfordshire Press.

Spencer-Wood, S.M. (1999). The world their household: Changing meanings of the domestic sphere in the nineteenth century. In P.M. Allison (Ed.), The Archaeology of Household Activities (pp. 16289). Routledge. https://doi.org/10.4324/9780203014929 
Standley, E. (2016). Spinning yarns: The archaeological evidence for hand spinning and its social implications, c AD 1200-1500. Medieval archaeology, 60(2), 266-99. https://doi.org/10.1080/00766 097.2016.1221264

Stark, M. (2017). Feminist theory after Deleuze. Bloomsbury.

Suggett, R. (2013). Peasant houses and identity in medieval Wales. Vernacular Architecture, 44, 6-18. https://doi.org/10.1179/0305547713Z.00000000011

Van Oyen, R. (2019). Rural time. World archaeology, 51(2), 191-207. https://doi.org/10.1080/00438243. 2019.1601461

Voss, B. (2008). Gender, race and labor in the archaeology of the Spanish colonial Americas. Current Anthropology, 49(5), 861-875. https://doi.org/10.1086/591275

Walker Bynum, C. (2015). Christian materiality. An essay on religion in late medieval Europe. Zone Books.

Weikert, K. (2015). The biography of a place: Faccombe Netherton, Hampshire, ca 900-1200. AngloNorman Studies, 37, 257-284.

Weikert, K. (2018). Of pots and pins: The households of late Anglo-Saxon Faccombe Netherton, Hampshire. In B. Jervis (Ed.), The Middle Ages Revisited: Studies in the Archaeology and History of Medieval Southern England Presented to Prof. David A. Hinton (pp. 58-70). Archaeopress. https:// doi.org/10.2307/j.ctvndv5s1

Whittle, J. (2013). Rural economies. In J. Bennett and R. Karras (Eds.), The Oxford Handbook of Women and Gender in Medieval Europe. Oxford University Press. https://doi.org/10.1093/oxfordhb/97801 99582174.013.024

Wickham, C. (2021). How did the feudal economy work? The economic logic of medieval societies. Past \& Present, 251, 3-40. https://doi.org/10.1093/pastj/gtaa018

Wilk, R., \& Rathje, W. L. (1982). Household archaeology. The American Behavioral Scientist, 25(6), 617-39. https://doi.org/10.1177/000276482025006003

Williams, J. (2000). Deleuze's ontology and creativity: Becoming in architecture. Pli, 9, 200-219.

Williams, J. (2019). Time and the posthuman: Rosi Braidotti and A. W. Moore on the posthuman and anthropocentrism after Deleuze's philosophy of time. In R. Braidotti and S. Bignall (Eds.), Posthuman Ecologies. Complexity and Process After Deleuze (pp. 105-22). Rowman \& Littlefield.

Wood, M.C. (2004). Working-class households as sites of social change. In K.S. Barile and J.C. Brandon (Eds.), Household Chores and Household Choices. Theorizing the Domestic Sphere in Historical Archaeology (pp. 210-34). University of Alabama Press. https://muse.jhu.edu/book/6640

Woodward, K., Jones, J. P., \& Marston, S. (2010). Of eagles and flies: Orientations towards the site. Area, 42(3), 271-280. https://doi.org/10.1111/j.1475-4762.2009.00922.x

Woodward, K., Jones, J. P., \& Marston, S. (2012). The politics of autonomous spaces. Progress in Human Geography, 36(2), 204-24. https://doi.org/10.1177/0309132511432083

Wrathmell, S., \& Roberts, B. (2003). Region and place: A study of English rural settlement. English Heritage. https://doi.org/10.5284/1028203

Wright, S.H. (2020). Medieval European peasant women: A fragmented historiography. History Compass, 18 (6) https://doi.org/10.1111/hic3.12615

Publisher's Note Springer Nature remains neutral with regard to jurisdictional claims in published maps and institutional affiliations. 